\title{
Dictators Walking the Mogadishu Line: How Men Become Monsters and Monsters Become Men*
}

\author{
Shaun $\operatorname{Larcom}^{\dagger}$
}

\author{
Mare Sarr ${ }^{\ddagger}$
}

February 2016

\begin{abstract}
History offers many examples of dictators who worsened their behavior significantly over time (like Zimbabwe's Mugabe) as well as dictators who displayed remarkable improvements (like Rawlings of Ghana). We show that such mutations can result from rational behavior when the dictator's flow use of repression is complementary to his stock of wrongdoings: past wrongdoings then perpetuate further wrongdoings and the dictator can unintentionally get trapped in a repressive steady state where he himself suffers from ex-post regret. This then begs the question why such a dictator would ever choose to do wrong in the first place. We show that this can be explained from the dictator's uncertainty over his degree of impunity in relation to wrongdoing, which induces him to experiment along this dimension. This produces a setting where any individual rising to power can end up as either a moderate leader, or as a dreaded tyrant. Since derailment is accidental and accompanied by ex-post regret, increasing accountability can be in the interest of both the public and the dictator.
\end{abstract}

JEL-classification: D72, D74, N47, O10, P16

Key words: Dictatorship, Repression, Political violence, Resource curse, Learning, Multiple steady states

\footnotetext{
*Many thanks to Denis Norman for sharing his experiences on life within the Mugabe-government. We also thank Rob Davies, Georgy Egorov, Bernardo Guimaraes, Juniours Marire, Athanasios Orphanides, Chrik Poortman, Ragnar Torvik, Wessel Vermeulen, Sam Wills, Li Yuan, Alex Zimper and audiences at the 7th Oxcarre Conference, the 2014 Political Economy Workshop in Milan, and the Universities of Cape Town, Oxford, Pretoria, Toulouse School of Economics, and the Graduate Institute Geneva for useful comments and discussions. Mare Sarr thanks Economic Research Southern Africa for financial support. Adeola Oyenubi provided excellent research assistance.

${ }^{\dagger}$ Department of Land Economy, University of Cambridge. E-mail: stl25@cam.ac.uk.

${ }^{\ddagger}$ School of Economics, University of Cape Town. E-mail: mare.sarr@uct.ac.za.

$\S$ External research associate, OxCarre. E-mail: timwillems85@gmail.com.
} 


\section{Introduction}

Let them hate me, as long as they fear me.

Caligula, Roman Emperor from 37 to $41 A D$.

At some point in the second half of the 20th century, the world was in a state of excitement. The reason was that the white government of an African country had just announced the discharge of a prominent freedom fighter with a history within the South African ANC. After decades of tireless struggle for freedom and majority rule, he was convincingly elected to lead his country. Despite past grievances, he advocated reconciliation between blacks and whites upon assuming presidency - a position that he started to fulfill with success. This didn't go unnoticed and the freedom-fighter-turned-politician was soon inundated with international honours (including a knighthood by Queen Elizabeth II in 1994). His name, however, wasn't Nelson Mandela. It was Robert Mugabe.

Anno 2016 the above paragraph may be hard to believe, but upon installation in 1980 (and even during his early years) Mugabe was regarded as a benevolent and highly competent ruler of his country - a view that was widely shared among Zimbabweans, nonZimbabweans, and international organizations. ${ }^{1}$ During the 1980s, Mugabe's government also achieved impressive successes: the country saw double-digit growth rates, high school enrolment rates increased from 2 percent to 70 percent, while literacy rates rose from 45 percent to 80 percent. Because of his contributions to reconciliation, Mugabe was even short-listed for the Nobel Peace Prize in the 1980s (Nordlinger, 2012: 243).

By the late 2000s, however, things had gone horribly wrong: over 90 percent of all Zimbabweans were unemployed, a fifth of them HIV-positive, and about 25 percent of the population had fled the country to look for a better life elsewhere. Many of those remaining in Zimbabwe lived under great fear and repression, with Mugabe stating in a 2003 speech that he would act like "a black Hitler tenfold" against any opposition. In order to finance the military, excessive money creation made inflation soar to 231 million percent in 2008. GDP per capita in the late 2000s was less than half of what it was back in the early 1980s. Meanwhile, life expectancy for Zimbabwean men fell from 58 years in

\footnotetext{
${ }^{1}$ On September 5 1986, The New York Times for example wrote in an editorial that "Zimbabwe under Mr. Mugabe's leadership remains one of Africa's success stories (...) His sensible economic policies have kept the country's key agricultural sector healthy. His responsible treatment of the white remnants of colonial Rhodesia has checked the flight of a skilled minority. Even the debilitating relations between black tribes seem to be less tense". When Mugabe won the Hunger Project Prize in 1988, he was credited with turning Zimbabwe into the "agricultural success story" of Africa, with his agricultural programs "[pointing] the way not only for Zimbabwe but for the entire African continent".
} 
1991 to 45 years in 2006. Female life expectancy nearly halved from 61 years in 1991 to no more than 34 years in 2006 (Holland, 2008: xxi).

In this paper, we ask how it is possible that someone who looked to be a promising ruler during his early years, ${ }^{2}$ subsequently became a dreaded tyrant. Any explanation for such a development should also address why someone who is off to a promising start, would ever choose to do wrong in the first place. This seems to be a pattern: next to the curious case of Robert Mugabe, there are many more examples of promising leaders who later turned into vicious dictators (see the Appendix to this paper).

At the exact same time, history also offers examples of dictators who started off in an unpromising (and even malevolent) manner, but showed remarkable improvements in their actions over time. The archetype along these lines is Ghana's Jerry Rawlings (Bueno de Mesquita and Smith, 2011: 218-222). Immediately after taking power in December 1981, he began a wave of oppression through killings, arrests, and torture, while he simultaneously ended free press. Subsequently, however, Rawlings was rapidly confronted with rising unrest among the local population (as well as with pressure from the international community). This turned him into, what Bueno de Mesquita and Smith (2011: 222) call, "a reluctant democrat". Notwithstanding his questionable motives, Rawlings had become a poster boy for the IMF and World Bank by the early 1990s and was credited with playing a key role in Ghanaian development. In December 2000, Rawlings stepped down per his own constitutional mandate (he had served for two terms) and made room for the democratically elected John Kufuor, his main rival and opponent in the 1996 election. In doing so, Rawlings established the first peaceful transition of power in Ghana since the country's independence in $1957 .^{3}$

Again, Rawlings is not the only case of a dictator whose behavior mutated for the better and some other examples are described in the Appendix.

This paper presents a new theory (focused on explaining the use of repression) which

\footnotetext{
${ }^{2}$ That is not to say that Mugabe had a flawless start. While the consensus view is that he did more good than harm during the first ten years of his reign, it certainly was not all good from the beginning: he for example already repressed certain political opponents during the 1980s (see especially Godwin (2010)), although it has been argued that the underlying conflict was actually fuelled by external forces (South Africa's apartheid regime in particular, see footnote 4 below). What does seem undisputed is that Mugabe's behavior deteriorated significantly over time, which is the focus of this paper.

${ }^{3}$ On Rawlings' remarkable story, also see The Guardian of January 5, 2001. There it is written that "in 1981 Jerry Rawlings gained power in a coup. For years (...) he allowed opponents to be persecuted and murdered. Then at the beginning of the $90 \mathrm{~s}$, he changed. He allowed democratic elections and gave citizens a liberal constitution. This has now prevented him from holding office for a third term. And [he] kept to this". Similarly The New York Times of January 9, 2009 notes that "Africa's vast stage has seen many complex players, but few match the contradictions of Mr. Rawlings, the ruthless military man who seized power at the age of 31 and then oversaw the summary executions of his rivals, only to later usher in a new era of prosperity and democracy. Mr. Rawlings (...) was an unlikely savior".
} 
is able to rationalize these remarkable mutations - both for the better, as well as for the worse. We will show that such transformations can arise without having to allude to a sudden exogenous change in the dictator's preferences.

In our model, citizens are able to oust a dictator via a revolution, but the dictator can reduce the probability of being overthrown by exercising repression (which can take the form of restricting freedom of speech, imprisoning or executing opponents, and so forth). Particularly motivated by recent events in Northern Africa, where various dictators were overthrown, we allow revolutions to succeed. Herewith, we relax the often-made assumption that revolutions do not occur in equilibrium (see e.g. Acemoglu and Robinson (2006, Ch. 6, 11) and Guimaraes and Sheedy (2013) on this assumption).

A key ingredient underlying our results is a complementarity between a dictator's flow-use of repression and his "stock of past wrongdoings" (a novel concept that will play a central role): when a dictator has committed wrongs in the past (of whatever form), he fears retribution for these bygone offences once overthrown and he becomes more willing to use repression (so as to reduce his probability of being ousted, and hence punished).

Anecdotal evidence indeed suggests that this mechanism has played an important role in explaining the use of repression for many of the aforementioned cases. Asked what has happened to Mugabe's heart, his ex-spin doctor Jonathan Moyo for example notes that "Gukurahundi ${ }^{4}(\ldots)$ is hanging over Robert Mugabe's head, partly explaining his desire or his need - to continue in office until he dies" (Holland, 2008: 183). For similar reasons, Godwin (2010: 122) highlights the view that Mugabe is a "prisoner of his own past" and also quotes the Zimbabwean politician Roy Bennett as saying that "[Gukurahundi] remains Mugabe's biggest motive for holding on to power: he fears that if he leaves office he will become victim to (...) retributive justice, the real blood-revenge."

We will show that such stock-flow complementarity in wrongdoings leads to the emergence of two steady states: one is characterized by light repression, while the other steady state comes with heavy repression. As a result, our model can give rise to significant deteriorations in dictator-behavior, but also to remarkable improvements. It can do so without having to resort to equilibrium-multiplicity; our model only features multiple steady states - the equilibrium remains unique (thereby preventing "anything" from happening). Interestingly, our model also implies that any individual rising to power has the potential to end up as either a moderate leader, or as a dreaded tyrant.

\footnotetext{
4 "Gukurahundi" refers to the killing of supporters of Mugabe's rival Joshua Nkomo during the 1980s for which Mugabe is held responsible. There is evidence that this conflict was actually fuelled by South Africa's apartheid regime in an attempt to destabilize Zimbabwe. See e.g. "Apartheid's Spies" in The Washington Post of October 22, 1989.
} 
Although this mechanism can account for the derailment of leaders who have burned their hands in the past (while it is simultaneously, and more surprisingly, also able to explain why some of these leaders improved their behavior over the years), it raises a puzzling question as well: why does a rational leader ever choose to burn his hands for the first time? We will show that he may be inclined to do this when he has imperfect foresight on his ability to "get away" with non-congruent actions (i.e.: actions that the leader wishes to implement for personal reasons, despite the fact that the public disapproves of them). In this respect, some leaders are able to push their own interests further than others. When a leader is uncertain on how far he can go, it may become rational for him to experiment along this dimension - even though he realizes that this puts him at risk of derailment (which actually makes the dictator worse off as we will see later on). In the words of T.S. Eliot: "Only those who will risk going too far can possibly find out how far one can go." Consequently, it is worth emphasizing that all results in this paper are driven by an interaction between the aforementioned complementarity, and the dictator's inclination to experiment (which stems from the fact that he is uncertain on how far he can push his own interests). We will show that this can explain how some agents rationally end up in a situation which they will regret ex-post.

The remainder of this paper is structured as follows. Section 2 sets out our model and describes its key properties, after which Section 3 will explain how this setup can give rise to significant mutations in dictator-behavior. In doing so, we will discuss the factors that determine whether a particular ruler will develop into a moderate leader, or into a vicious tyrant. Section 4 then analyzes some policy implications, after which Sections 5 and 6 will discuss and conclude, respectively.

\section{Model}

\subsection{Setup}

Our model's structure is related to that of the drug addiction-model of Orphanides and Zervos (1995). It has an infinite horizon, is set in discrete time, and hosts an incumbent, non-accountable dictator who discounts the future with factor $\beta$. As argued in Maskin and Tirole (2004), such non-accountable officials are inclined to act in a way that is noncongruent with the preferences of society (so in the language of Hess and Orphanides (2001), the dictator is only "partially benevolent"). The reason is that the absence of an election mechanism implies that the public has relatively little means available through which it can ensure that the dictator acts in the public - as opposed to his private - 
interest (apart from trying to remove a dictator via a revolution, which is an option that we discuss below). We model the non-congruence by assuming that the dictator obtains utility $u\left(c_{t}, \cdot\right)$ by extracting $c_{t}$ rents from his country, for example through corruption. This is similar to Besley (2004: 201), who models non-congruent policy makers as ones who "obtain private benefits from deviating from the voters' preferred policy", for example because they are "willing to accept bribes". Simultaneously, however, such rent extraction creates discontent among the population, and may trigger a revolution (see below). ${ }^{5}$

Next to his private consumption level $c_{t}$, the dictator also controls the amount of repression that he is going to impose upon his population $\left(r_{t}\right) .{ }^{6}$ This variable can be set independently from $c_{t}$. We define "repression" as a technology that makes the aforementioned revolution less likely to succeed, ${ }^{7}$ while we also allow for the possibility that the dictator is sadistic and enjoys direct utility from implementing repressive policies. Consequently, the dictator's period utility function reads $u\left(c_{t}, r_{t} ; \rho\right)$, where $\rho \geq 0$ is a parameter that governs the dictator's degree of sadism (with $\rho=0$ representing a nonsadistic dictator whose utility function is simply given by $\left.u\left(c_{t}\right)\right)$. We will take this utility function to be twice continuously differentiable, increasing and strictly concave in both of its arguments.

The amount of divertible funds available to the dictator in any period is denoted by $z$. These funds can for example stem from the exploitation of natural resources, or from the

\footnotetext{
${ }^{5}$ As argued in Svolik (2012: 10), pursuing policies through which public consent is lost, always tends to be the "original sin" of dictatorships. Often, this original sin is rent extraction, think about the notable examples of the Roman Emperor Nero (who lost credit when he increased taxes to finance his "Golden House"), Kwame Nkrumah (he expropriated cocoa farmers, which led to violent insurgencies against his regime), and Ferdinand Marcos (the first protests that he faced, the so-called "First Quarter Storm", were triggered by the corruption in his government). More generally, one can think of $c_{t}$ as representing any non-congruent policy that the dictator wants to pursue for private reasons, even though it generates dissatisfaction among the population. It could also include military actions that a dictator has to take to land in power and/or stabilize the country. While such actions could be approved by the public in the "fog of war", they may be perceived less favorably later on.

${ }^{6}$ Besley and Persson (2011) distinguish between "repression" (which they define as the government using one-sided violence against a non-violent opposition) and "civil war" (in which case the opposition answers by using violence as well). Since we do not need to take a stand on the nature of the opposition (violent or non-violent?), this distinction becomes of subordinate importance to our model. Our model does distinguish between "peace" on the one hand, and "repression/civil war" on the other though.

${ }^{7}$ We thank a referee for pointing us to the large literature examining the relationship between repression and dissent (Snyder (1976), Lichbach (1987), Gupta, Singh, and Sprague (1993), Rasler (1996), Moore (1998) and Carey (2006)). The empirical findings of these studies are mixed - hinting at the existence of non-linearities. We acknowledge that repression could lead to an increase in anger among the populace which can actually reduce the dictator's chances of survival. In that case, our (rational) dictator would never choose to implement such policies. Given that we are focusing on autocracies, we make the assumption that we are in the range of repression where "anger gives way to fear" (see Lichbach (1987) and Carey (2006)). Consequently, an increase in repression succeeds in bringing down the probability with which the revolt succeeds (and the dictator may become willing to use this strategy).
} 
reception of fungible development aid. We take $z$ to be constant over time, as making it stochastic or time-varying does not yield many interesting insights (but see Section 4 for some comparative statics with respect to this variable). The dictator's budget constraint is then given by (we assume that the relative price equals unity, but this is of course without loss of generality):

$$
c_{t}+r_{t} \leq z
$$

Since we are not interested in explaining asset accumulation of dictators, we keep the model as simple (and parsimonious in terms of state variables) as possible by denying the dictator the opportunity to save any of his period endowment (but this assumption is not material to any of our results).

Once citizens find it worthwhile to revolt (a decision that we will discuss shortly), the dictator faces a probability $p_{t}=p\left(r_{t}\right)>0$ of being ousted in period $t$. This function satisfies $d p\left(r_{t}\right) / d r_{t}<0$, capturing the idea that a dictator can reduce the probability of being overthrown at time $t$ by repressing his population during that period.

Both the consumption of rents $c$ as well as the use of repression $r$ however generate dissatisfaction among the population. By carrying out such activities, a dictator may therefore trigger the start of a revolution, while he may also face corresponding punishment (if overthrown). Consequently, the combined stock of exercised repression and extracted rents $(S)$ will serve as a state variable. We refer to this novel concept as the dictator's "stock of wrongdoings" and it evolves according to:

$$
S_{t+1}=\delta S_{t}+r_{t}+\chi c_{t}
$$

Here $\delta \in(0,1)$ governs the depreciation rate (a lower value for $\delta$ implies that past wrongdoings are forgiven, or forgotten, at a faster pace), ${ }^{8}$ while $\chi \geq 0$ is the exchange rate converting units of rent extraction into units of repression (when $\chi<1$ extracting a unit of rents is seen as less malicious than exercising a unit of repression, and vice versa).

\footnotetext{
${ }^{8}$ In reality, $\delta$ seems to be smaller than 1 . This is partly due to statutes of limitations, but crimes also seem to be forgiven/forgotten over time: recall how Muammar Gaddafi was re-embraced by many countries in the early 2000s, while Rawlings, Moi, and many others were never prosecuted for their past alleged misdeeds. The ordinary public also seems to forgive/forget: Joseph Stalin's popularity among Russians has risen with time, while Kwame Nkrumah was voted "Africa's man of the millennium" in 2000. As a referee pointed out, the rate at which a crime is forgiven/forgotten may also depend upon the nature of a crime. This can be modeled by distinguishing between the stock of rent extraction $C$ and the stock of repression $R$ and applying different discount factors to the two stocks. Then, $S_{t}=$ $R_{t}+\chi C_{t}, R_{t+1}=\delta_{R} R_{t}+r_{t}, C_{t+1}=\delta_{C} C_{t}+c_{t}$, where having $\delta_{C}<\delta_{R}$ captures the idea that rent extraction $(c)$ is more easily forgiven/forgotten than repression $(r)$. Allowing for this generalization does not affect any of the results central to this paper.
} 
This state variable plays a dual role in our model. Firstly, once overthrown a dictator is punished according to the unforgotten/unforgiven stock of wrongdoings undertaken in the past. Secondly, citizens will use the accumulated stock $S$ to determine whether they find it worthwhile to start a revolution against the incumbent dictator. ${ }^{9}$

In particular, let us use $S^{*}$ to denote the value of $S$ beyond which (part of) the population starts a revolution. ${ }^{10}$ The exact location of this tipping point is affected by factors ranging from culture (Gorodnichenko and Roland, 2014) to geography (Campante, Do, and Guimaraes, 2013). However, the quality of institutions is an important determinant as well. Better institutions place tighter constraints on the executive (cf. how only democracies tend to provide legitimate channels for voicing dissent; Regan and Henderson (2002) and Carey (2010)) - thereby lowering the value of $S^{*}$. Under the simplifying assumption that lowering the location of the tipping point is costless, citizens would evidently like to set $S^{*}$ as low as possible. Consequently, $S^{*}$ may be thought of as the lowest value of the tipping point that civilians can choose, given the relevant exogenous factors - such as culture and geography. (Obviously, when we assume that reducing the position of the tipping point is costly, $S^{*}$ would be left at a higher location; in that sense, $S^{*}$ can be seen as an absolute lower bound.)

We use the term "revolution" very broadly here and allow it to encompass all actions that citizens can undertake with the aim of overthrowing the incumbent. These actions could be either violent or non-violent, so "opposition" is another appropriate label. With some abuse of terminology, we will call the point $S^{*}$ "the Mogadishu line". ${ }^{11}$ From that point onwards, the dictator faces a period ousting probability equal to $p\left(r_{t}\right)$, which he can reduce by exercising repression (remember that $d p\left(r_{t}\right) / d r_{t}<0$ and recall that our

\footnotetext{
${ }^{9}$ One could also introduce a third role for $S$ by using a more general ousting probability function of the form $p\left(S_{t}, r_{t}\right)$, with $\partial p\left(S_{t}, r_{t}\right) / \partial S_{t}>0$. This would capture the idea that the public becomes more eager to bring about regime change, or that a larger fraction of the population joins the revolution, if the dictator's accumulated stock of wrongdoings is bigger. For simplicity we employ $p\left(r_{t}\right)$, but our results are fully robust to using the more general $p\left(S_{t}, r_{t}\right)$.

${ }^{10}$ If we were to microfound $S^{*}$, this would be the level of $S$ beyond which it would be optimal for citizens to start revolting, taking all future possibilities (which include derailment, disciplining, and ousting of the dictator) into account. Since modeling this group-decision is non-trivial due to the presence of a collectiveaction problem (Acemoglu and Robinson, 2006: Ch. 5) and a need to specify how the public believes that the dictator will react to any opposition, we take a short-cut here - choosing to highlight (and microfound) the behavior of the dictator instead. For our mechanism to operate, the only important element is that there is a threshold - how exactly it comes about is of subordinate importance. Most existing models of revolutions, such as the seminal ones by Roemer (1985), Grossman (1991), and Wintrobe (1998), take a similar approach on this dimension.

${ }^{11}$ Formally, the concept of "the Mogadishu line" refers to the point where a foreign power abandons a pure peacekeeping mission in a particular country and begins combat operations instead, often with the aim of bringing about regime change. In this paper, we will use the term more generally so that it also includes the mobilization of a local opposition that wants to overthrow the incumbent regime.
} 
results are robust to using the more general function $p\left(S_{t}, r_{t}\right)$, with $\partial p\left(S_{t}, r_{t}\right) / \partial S_{t}>0$ and $\partial p\left(S_{t}, r_{t}\right) / \partial r_{t}<0 ;$ cf. footnote 9$)$.

The fact that the revolution only starts once $S_{t}>S^{*}$, results from the notion that individuals need to pay a fixed start-up cost to form an opposition-movement. ${ }^{12}$ This feature of our model ensures that dictators can get away with some wrongdoing, which seems to be in line with reality: a revolution only arises once the public's assessment of the dictator gets "bad enough". ${ }^{13}$ Agents in our model thus look at a dictator's past performance in determining whether they find it worthwhile to revolt, which seems realistic and is somewhat analogous to the concept of retrospective voting (and note that such backward-looking behavior is not necessarily inconsistent with rationality; cf. Rogoff and Sibert (1988), Rogoff (1990), and Alesina and Cukierman (1990)).

The exact location of the Mogadishu line $S^{*}$, a tipping point beyond which a revolution mobilizes, is however unknown to the dictator (and see Kuran (1989) for evidence that the locations of such points are indeed surrounded by uncertainty). Consequently, the dictator is unsure about how much of the utility-generating non-congruent policy (in our setup: how much rent extraction) he can get away with, which is why he may choose to experiment along this dimension. Uncertainty on the location of the tipping point implies that there is a chance that initial wrongdoings will remain unpunished. Consequently, a dictator may become willing to "burn his hands" for the first time - even though he anticipates that this could lead to ex-post regret (since initial wrongdoings can perpetuate future ones, as will become clear later on).

The position of $S^{*}$ is only revealed to the dictator once his actual stock $S_{t}$ crosses $S^{*}$, as he then observes the mobilization of an opposition-movement. If he observes no opposition at time $t$, the dictator learns that $S^{*}>S_{t}$ and he updates his prior belief on the location of $S^{*}$ accordingly using Bayes' rule. Summarizing the dictator's prior belief about the location of $S^{*}$ with the c.d.f. $F\left(S^{*}\right)$, this implies that if $S^{*}$ has not yet been reached at the point where the stock of wrongdoings equals $S$, the distribution is updated

\footnotetext{
${ }^{12}$ See e.g. Acemoglu and Robinson (1999), Cabrales and Hauk (2011), and Fearon (2011) for similar models. One could also allow for an exogenous positive probability of the dictator losing power while $S_{t}<S^{*}$ without affecting our results. That specification would make this case correspond to the state of peace identified by Besley and Persson (2011): in their peace-regime there is also no repression or revolution occurring, but the incumbent does face an exogenous probability of losing power.

${ }^{13}$ American "Founding Father" John Adams already noted this in his Papers, where he wrote that "people are so little attentive to government that there are no instances of resistance until repeated, multiplied oppressions have placed it beyond a doubt that their rulers had formed settled plans to deprive them of their liberties" (Adams, 1977 [1775]: 231).
} 
to $F^{\prime}\left(S^{*}\right)$ via (see Zeira $\left.(1987,1999)\right)$ :

$$
F^{\prime}\left(S^{*}\right)=\frac{F\left(S^{*}\right)-F(S)}{1-F(S)}
$$

Without loss of generality, $F(\cdot)$ will be the uniform c.d.f. with support $\left[0, S_{\max }\right]$.

In this paper we model the Mogadishu line $S^{*}$ as being exogenous, but this is not essential. One could for example also endogenize $S^{*}$ by making it depend on $r$, without affecting the core findings that are to follow. All that matters for the main results is that there is a threshold $S^{*}$ and that its exact location is unknown.

As a result of our model's information structure, the dictator's behavior is characterized by two value functions. After the dictator has crossed the Mogadishu line $S^{*}$, its location is revealed through the start of a visible revolution and the learning process stops. Assuming that the opposition-movement stays active ever after it has incurred the fixed start-up cost, crossing the tipping point is an irreversible event and the "post-tipping" value function $V_{1}$ is given by:

$$
V_{1}(S)=u(c, r)-p(r) \Psi(S)+[1-p(r)] \beta V_{1}\left(S^{\prime}\right)
$$

where non-primed variables refer to the current period, while primed variables apply to the next period. If the dictator is ousted in the current period (which happens with probability $p(r)$ ), he incurs a punishment $\Psi$ which is increasing in his accumulated stock of unforgiven/unforgotten wrongdoings (so $d \Psi(S) / d S>0$ ).

As long as $S<S^{*}$ the dictator hasn't crossed the Mogadishu line yet, so he is uncertain on the exact location of $S^{*}$. The dictator therefore uses his beliefs $F\left(S^{*}\right)$ to construct expected values. The pre-tipping value function $V_{0}$ can then be written as:

$$
V_{0}(S, F)=u(c, r)+\beta\left[\left(1-q\left(S^{\prime}, S\right)\right) V_{0}\left(S^{\prime}, F^{\prime}\right)+q\left(S^{\prime}, S\right) V_{1}\left(S^{\prime}, F^{\prime}\right)\right]
$$

where $q\left(S^{\prime}, S\right)$ expresses the dictator's belief that $S^{*}$ is located in the $\left(S, S^{\prime}\right)$-interval (i.e. that $S^{*} \in\left(S, S^{\prime}\right)$ ). This belief is defined by:

$$
q\left(S^{\prime}, S\right) \equiv \operatorname{Pr}\left[S^{*} \in\left(S, S^{\prime}\right)\right]=F\left(S^{\prime}\right)-F(S)
$$

Hence, $q\left(S^{\prime}, S\right)$ represents the subjective probability that the dictator attaches to switching to the post-tipping regime if he chooses to set next period's stock of accumulated wrongdoings equal to $S^{\prime}$ (with his current stock being equal to $S$ ). Through this mechanism a dictator realizes that by committing any wrongs in the current period, he 
loses popularity and hence increases the probability that he will be ousted in the future. ${ }^{14}$ This completes the description of our model's setup.

\subsection{Solution}

The model can be solved through value-function iteration. Moreover, when the dictator has sadistic preferences (i.e.: when $\rho>0$ ) and when rent extraction does not feed into the stock $S$ (i.e.: when $\chi=0$ ), it is possible to establish some important properties of the solution analytically. This is possible thanks to Lemma 1, which enables us to reduce our problem to a problem which has been solved before.

LEMma 1. When $\rho>0$ and $\chi=0$, the budget constraint (1) will hold with equality in the post-tipping regime.

Proof. In this case, the post-tipping problem reads:

$$
\begin{aligned}
V_{1}(S) & =\max _{c, r} u(c, r)-p(r) \Psi(S)+[1-p(r)] \beta V_{1}\left(S^{\prime}\right) \\
\text { s.t. } S^{\prime} & =\delta S+r \\
z & \geq c+r
\end{aligned}
$$

The Lagrangian can thus be formulated as:

$$
\mathcal{L}=u(c, r)-p(r) \Psi(S)+[1-p(r)] \beta V_{1}\left(S^{\prime}\right)-\lambda[c+r-z]-\mu\left[\delta S+r-S^{\prime}\right]
$$

From the first-order conditions it follows that:

$$
\frac{\partial \mathcal{L}}{\partial c}=\frac{\partial u}{\partial c}-\lambda=0
$$

which implies that $\lambda=\partial u / \partial c>0$, hence the constraint binds.

By using Lemma 1, we can eliminate the budget constraint from our post-tipping problem by defining $v(c) \equiv u(c, z-c)$. Consequently, the post-tipping dynamic programming problem can be written as:

$$
\begin{aligned}
V_{1}(S) & =\max _{c \in[0, z]}\left\{v(c)-p(z-c) \Psi(S)+[1-p(z-c)] \beta V_{1}\left(S^{\prime}\right)\right\} \\
\text { s.t. } S^{\prime} & =\delta S+z-c
\end{aligned}
$$

\footnotetext{
${ }^{14}$ Niccolò Machiavelli also alluded to this in The Prince, where he wrote: "Never do any enemy a small injury for they are like a snake which is half beaten and it will strike back the first chance it gets".
} 
This casts our model back into the general framework of Orphanides and Zervos (1994, 1995), which enables us to establish the equivalents of Propositions 1-6 in Orphanides and Zervos (1995). Since their Propositions 3-6 are of subordinate importance to our paper, we only repeat our equivalents of their first two propositions here (Proposition 1 dealing with existence and uniqueness, while Proposition 2 establishes important characteristics of the model's steady state(s)):

Proposition 1. There exists a unique and continuous value function $V_{1}(S)$ that satisfies (7), as well as a nonempty, upper semicontinuous policy correspondence which describes the optimal evolution of the stock:

$$
\Phi(S)=\left\{S^{\prime}: V_{1}(S)=v(c)-p(z-c) \Psi(S)+[1-p(z-c)] \beta V_{1}\left(S^{\prime}\right)\right\}
$$

Proof. See Orphanides and Zervos (1995).

Proposition 2. For a dictator in the post-tipping regime, (i) optimal paths converge monotonically to a steady state, (ii) if the stock at the time-of-tipping resides between two consecutive steady states, then the optimal paths converge to one or the other, and (iii) there is exactly one critical level between any two consecutive stable steady states.

Proof. See Orphanides and Zervos (1994).

When $\rho=0$ and/or $\chi>0$, Lemma 1 no longer applies and the Propositions in this section can not be proved. Extensive numerical analysis however strongly suggests that they continue to apply.

The global monotonicity underlying the optimal evolution of the stock $S$ allows for a simple graphical illustration of the post-tipping policy function, an example of which can be found in Figure 1. From it, the steady-state multiplicity stands out. To understand this important feature of our model, note from the post-tipping value function $V_{1}$ (equation (4)) that the stock of wrongdoings and the flow of repression are complements. Defining $g(c, r, S) \equiv u(c, r)-p(r) \Psi(S)$ as the dictator's period felicity function in the post-tipping regime, it holds that:

$$
\frac{\partial^{2} g(c, r, S)}{\partial r \partial S}=-\frac{d p(r)}{d r} \frac{d \Psi(S)}{d S}>0
$$

as $d p(r) / d r<0$ (a dictator can reduce the probability with which he is ousted by exercising repression), while $d \Psi(S) / d S>0$ (punishment is increasing in the stock of accumulated wrongdoings). This shows that marginal utility from exercising repression is higher for a dictator with a large stock of wrongdoings hanging over his head - thereby 
making it more likely that such a dictator will do further wrongs (in the form of repressing his population, as that reduces the probability that he will indeed face punishment).

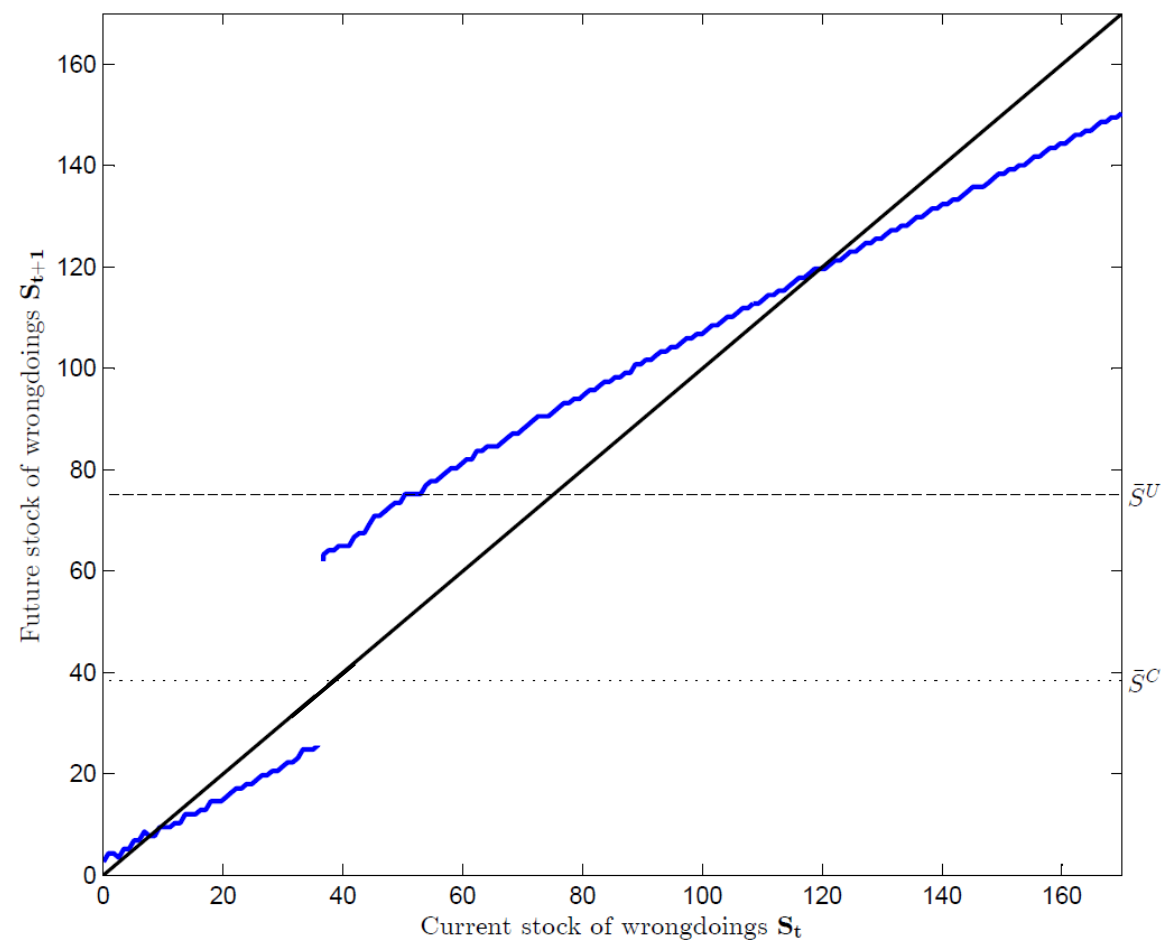

Figure 1: Illustration of the post-tipping policy function for $u(c)=\log (c), \rho=0, p(r)=$ $\frac{1}{1+\exp (\kappa r)}, \Psi(S)=S, \beta=0.95, \delta=0.6, \chi=0.6, \kappa=0.073$, and $z=50$.

As set out in a general setup by Orphanides and Zervos (1994), this complementarity leads to a multiplicity of steady states. In our setting, this multiplicity is driven by a discontinuity in the dictator's post-tipping policy function. ${ }^{15}$ Denoting the location of the discontinuity by $S^{D}$, we will show in Section 3 that this stock $S^{D}$ is going to act like a critical point in our model - generating two steady states for the stock of wrongdoings $S$ in the post-tipping regime.

Intuition for this multiplicity can be gained by realizing that all that the dictator cares about, is the product $p(r) \Psi(S)$ (recall equation (4)). Due to the complementarity between $S$ and $r$, there is one steady state where both $S$ and $r$ are high (the former making prospective punishment $\Psi(S)$ high, while the latter reduces the probability of it

\footnotetext{
${ }^{15}$ As noted by Orphanides and Zervos (1994), existence of the discontinuity is not guaranteed, but its presence is not essential: they show that the steady-state multiplicity also arises when the policy function is continuous (as one then obtains an S-shaped policy function, yielding an unstable intermediate steady state acting like a critical point). In all cases with steady-state multiplicity that we have looked at, the discontinuity is present.
} 
actually materializing $p(r)$ - such that the product $p(r) \Psi(S)$ remains contained). The other steady state is characterized by the co-existence of a low $S$ and $r$. In that case, prospective punishment $\Psi(S)$ is already low, as a result of which there is no need to ensure a low $p(r)$ by setting a high $r$. Which steady state the model will end up in, is fully determined by the ranking of $S^{D}$ relative to $S^{*}$ (see Section 3). Consequently, the equilibrium of our model remains unique (despite the steady-state multiplicity).

As pointed out by Orphanides and Zervos (1995), further analytical results are scarce in these kind of models but progress can be made by analyzing limit cases. For our setting, a useful limit case is the one in which a dictator holds the belief that there is no tipping point. In that case, our optimization problem becomes purely static and can be solved analytically. Since the dictator in this case believes that there is absolutely no chance that he will ever be overthrown via a revolution (either now or in the future), he will always choose to exhaust his budget constraint (2) by setting $c=z$. The accompanying steady-state stock equals $\bar{S}^{U}=\chi z /(1-\delta)$, where the superscript $U$ indicates that this is the unconstrained steady state.

A decision maker who believes that there may exist an unpleasant tipping point at some bounded location (i.e. someone who believes that $S^{*}<\infty$ is possible, but is unsure on its exact position), will behave more cautiously (see Zeira (1987) and imagine the speed at which a blind man would walk towards his goal if he knew that there might be a cliff somewhere in front of him). In our environment, this implies that the dictator will choose to extract less rents in the pre-tipping regime compared to the unconstrained case, increasing his stock $S$ only little-by-little as he is afraid to cross $S^{*}$ (such caution is also apparent from Figures 2 and 3 below). Due to this more cautious behavior, the model will settle down at a lower steady state $\bar{S}^{C}<\bar{S}^{U}$. It is not possible to solve for this "constrained" steady state $\bar{S}^{C}$ analytically, but it can be found numerically. The dotted line in Figure 1 shows its location given parameters. The constrained steady state $\bar{S}^{C}$ is useful as it characterizes the limit behavior of any dictator who becomes increasingly optimistic that the possibility of a revolution is not going to generate a binding constraint on him (i.e.: a dictator who starts to put more and more weight on the possibility that $S^{*}>\bar{S}^{C}$ ). Once his stock $S_{t}$ reaches $\bar{S}^{C}$ (without having triggered a revolution), the system will settle down at this steady state. ${ }^{16}$

\footnotetext{
${ }^{16}$ To avoid clutter, Figure 1 does not contain the pre-tipping policy functions for dictators who believe that either $S^{*}=\infty$ or that $S^{*}<\infty$. They are however just two continuous, upward-sloping lines crossing the $45^{\circ}$-line at $\bar{S}^{U}$ and $\bar{S}^{C}$, respectively.
} 


\section{Simulation results}

At this stage, we can gain further insights by simulating the choices that a dictator who is placed in our model-environment will make. For reasons that are set out below, we will start by considering a non-sadistic dictator with $\rho=0$ (but the case where $\rho>0$ is analyzed later on). As will become clear in this section, the relative ranking of the critical point $\left(S^{D}\right)$ and the Mogadishu line $\left(S^{*}\right)$ becomes a key determinant of how the dictator will act. Consequently, we distinguish between two cases.

Case I: $S^{D}<S^{*}$. First consider Figure 2 (which is the simulation that follows from Figure 1 and its calibration). The solid line in the top panel of this figure shows the outcome of a typical simulation when the Mogadishu line $S^{*}$ is greater than the critical point $S^{D}$ (but smaller than $\bar{S}^{C}$, so $S^{D}<S^{*}<\bar{S}^{C}$ ). ${ }^{17}$ The solid line shows that, even though the dictator is not fully benevolent from the start due to his non-congruent preferences, ${ }^{18}$ his behavior is still quite moderate during his early days (especially if one considers what is about to follow). This characterization fits the cases of Robert Mugabe and many others who were not perfect when they first came to power, but looked bearable at least.

Uncertain on where exactly the Mogadishu line $S^{*}$ is located (and hence uncertain on how much wrongdoing he can get away with before mobilizing the opposition), the dictator continues to experiment by implementing his non-congruent interest. As can be inferred from the bottom panel of Figure 2, the wrongdoings in the pre-tipping regime consist entirely of rent extraction (the difference between the solid and the dashed line in Figure 2 's bottom panel equals $\chi c_{t}$, which is rent extraction converted to units of repression); there is no repression yet. The reason is that in the model's current formulation, the dictator is non-sadistic $(\rho=0)$ and repression only starts delivering benefits after the opposition has mobilized. Consequently, a dictator will never exercise any repression as long as his stock $S<S^{*}$ and our model starts out in a state of peace. One could let a dictator exercise repression while $S<S^{*}$ by assuming that any pre-tipping use of repression pushes up the location of $S^{*}$, or by considering a sadistic ruler for whom $\rho>0$

\footnotetext{
${ }^{17}$ Whenever exogenous factors are such that $S^{*}>\bar{S}^{C}$, the tipping point is "non-binding" and the dictator is able to reach his constrained steady state $\bar{S}^{C}$ without triggering a revolution. This case is illustrated by the dotted, circled curve in Figure 2 (this curve is actually more visible in Figure 3 below).

${ }^{18}$ Given our framing, the dictator starts by extracting rents. But as explained in footnote 5 , one can think of $c_{t}$ as representing any policy that the dictator wants to pursue for private reasons - even though it creates dissatisfaction among the public. It could also be the case that external circumstances make a dictator believe (rightly or wrongly) that he is somehow forced to take a non-congruent action. Some might argue that this was the case for Robert Mugabe around Gukurahundi (recall footnote 4).
} 
(see under Case II below). Those versions of the model yield similar results. In this section we would however like to emphasize that even non-sadistic rulers can end up as vicious tyrants.
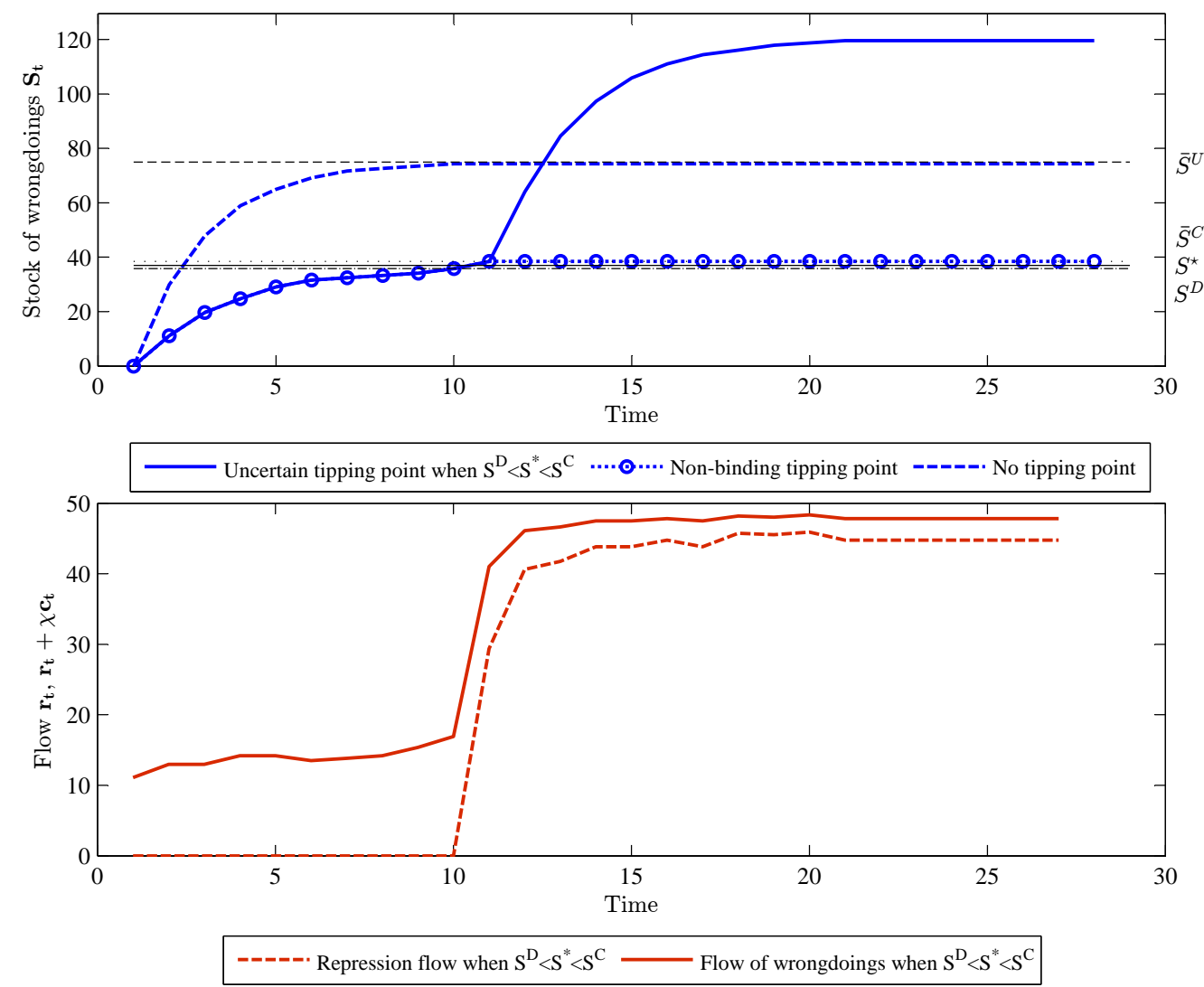

Figure 2: Evolution of key variables when $S^{D}<S^{*}$. Parameters as in Figure 1.

From the top panel one can also see how the dictator's behavior is moderated by his belief that there may exist a binding tipping point (recall the end of Section 2 and compare the start of the solid line in Figure 2's top panel with the dashed line, which would materialize if the dictator was certain that there was no tipping point). As the revolution fails to materialize, our dictator becomes increasingly optimistic that he can get away with extracting even more rents and he continues with his unlawful behavior. ${ }^{19}$ The dictator hopes to be able to reach his constrained steady state $\bar{S}^{C}$ without triggering a revolution by continuing along his initial path (this case is illustrated by the dotted, circled curve in the top panel of Figure 2 and would materialize if $S^{*}>\bar{S}^{C}$, i.e. if the tipping

\footnotetext{
${ }^{19}$ Anecdotal evidence indeed suggests that this learning/experimentation process on how far one can go, plays a role in reality. Holland (2008: 66) for example describes how Robert Mugabe started to believe that "he could get away with anything" after Gukurahundi was left unpunished.
} 
point were "non-binding"). ${ }^{20}$ But when his stock of wrongdoings $S_{t}$ eventually crosses $S^{*}$ nevertheless (in our example this happens just before $\bar{S}^{C}$ is reached), the oppositionmovement is mobilized and the dictator finds himself in the post-tipping regime.

As Figure 2 shows, the model then converges to the bad steady state, characterized by heavy repression. The reason is that our dictator switches to the post-tipping policy function (displayed in Figure 1) with a stock $S_{t}>S^{D}$ (this is guaranteed by Case I's defining assumption that $S^{*}>S^{D}$ ). In that part of the state space, the bad steady state is the stable point of attraction. Intuitively, our dictator has accumulated such a large stock of wrongdoings that he fears retribution and has become "a prisoner of his own past" who has crossed "a point of no return" (cf. the remarks that commentators have made about Mugabe and Nkrumah in the Introduction and Appendix to this paper). All the dictator can do is hope to avoid serious punishment by clinging on to power, even though this requires additional wrongdoings on his behalf (namely exercising repression). In this steady state, a high stock of wrongdoings $S$ (which implies a high prospective punishment $\Psi(S)$ for the dictator) will be accompanied by heavy use of repression $r$ (to reduce $p$, so that $\Psi(S)$ is unlikely to materialize). With the flow use of repression and the stock of wrongdoings being complements, the dictator finds the established reduction in $p_{t}$ worthwhile, despite the fact that his use of repression $r_{t}$ also adds to $S_{t+1}$ (which increases his problems even further if he does get overthrown in the future). At this stage, the dictator can live with being hated - as long as he is feared as well (recall Caligula's quote in the Introduction).

It is interesting to note that in our model, derailment of a dictator is unintentional, yet voluntary and accompanied by ex-post regret (even though it results from rational behavior): had the dictator known the exact location of $S^{*}$, he never would have started the experimentation process and he never would have crossed this line. It is thus the informational imperfection on the location of $S^{*}$ that opens up the possibility to accidental derailment of the dictator. ${ }^{21}$

\footnotetext{
${ }^{20}$ This does require the dictator's initial subjective belief to be sufficiently optimistic such that he puts some prior probability on the possibility that $S^{*}>\bar{S}^{C}$. Given that many dictators suffer from a feeling of "grandiosity" (Coolidge and Segal, 2009), such (over-)confidence in their ability to get away with some wrongdoings is likely to be present in reality.

${ }^{21}$ In this sense, our model is similar to the drug addiction-model of Orphanides and Zervos (1995): their model produces drug addicts to whom addiction was unintentional and accompanied by ex-post regret. As they note (p. 740), the crucial element to obtain this result is to do away with the assumption of perfect foresight. Once that assumption is relaxed, models in which agents behave rationally can already produce these kind of results. The same applies to our model: we have relaxed the perfect foresight-assumption by introducing uncertainty on the location of $S^{*}$, as a result of which the dictator is uncertain on how much wrongdoing he can actually get away with, which seems realistic.
} 
Anecdotal evidence supports the notion of ex-post regret. In Holland (2008: 121), Denis Norman (an Englishman who spent a total of twelve years in Robert Mugabe's cabinet, but subsequently distanced himself from the regime) recalls a private conversation that he had with Mugabe in 2003 (during which Mugabe had little incentive to lie). Norman asked him "Where did it all go wrong?", to which Mugabe replied: "Things aren't what they used to be, are they?". Mugabe subsequently reflected upon the trips that he and Norman used to make across the country (before things got out of hand), adding "Those were good days, weren't they? I really enjoyed it all back then." ${ }^{22}$

Finally, we would like to emphasize that it really is the interaction between the informational imperfection on the location of $S^{*}$ and the complementarity between $S$ and $r$ that is generating the behavioral transformation. Neither ingredient by itself would be enough: without imperfect information there would be no experimentation and the dictator would never cross the Mogadishu line, while there would be no derailment if it wasn't for the complementarity. It is only as a result of the interaction that rational agents may voluntarily choose to engage in actions that they might come to regret ex-post.

Case II: $S^{D}>S^{*}$. Now consider Figure 3. This figure was generated using the parameterization of Figure 2, only now $S^{*}<S^{D}$. As the two dashed lines in the top panel of this figure show, the model would converge to the exact same steady states as under Case I if the dictator either knew that there is no tipping point (the dashed line converging to $\bar{S}^{U}$ ) or if he did expect a tipping point at a bounded location but the tipping point happens to be non-binding (the dashed-circled line converging to $\bar{S}^{C}$ ).

The solid line in the top panel shows a typical simulation when the tipping point is binding $\left(S^{*}<\bar{S}^{C}\right)$ and when the discontinuity $S^{D}$ is located to the right of the Mogadishu line $S^{*}\left(S^{*}<S^{D}\right.$; this is the contrast with Case I). Here, the dictator learns the location of the tipping point before his stock $S_{t}$ has crossed the critical point at $S^{D}$. For the first few periods, while in the pre-tipping regime, this dictator makes the exact same choices as under Case I. But since the opposition now mobilizes relatively early (before the dictator has accumulated a stock of wrongdoings which exceeds $S^{D}$ ), it isn't too late for him yet to improve his behavior upon learning the location of $S^{*}$. Under this case, the dictator switches to the post-tipping policy function with a stock $S_{t}<S^{D}$. In that area of the

\footnotetext{
${ }^{22}$ In Godwin (2010: 122), Mugabe's personal chaplain characterizes him as an unhappy ruler as well. Such discontent is also apparent in the private notes of Tsar Nicholas II of Russia, who inherited a repressive regime from his father, Alexander III . After Bloody Sunday (22 January, 1905), he wrote in his personal diary: "A painful day. There have been serious disorders in St. Petersburg because workmen wanted to come up to the Winter Palace. Troops had to open fire in several places in the city; there were many killed and wounded. God, how painful and sad."
} 
state space, the good steady state is the stable point of attraction (recall Figure 1). So when $S^{*}<S^{D}$, the opposition manages to discipline the dictator. This kind of behavior has been observed in reality around the cases of Jerry Rawlings and many others, who all turned into moderate leaders after their rather unpromising starts were met with protests.

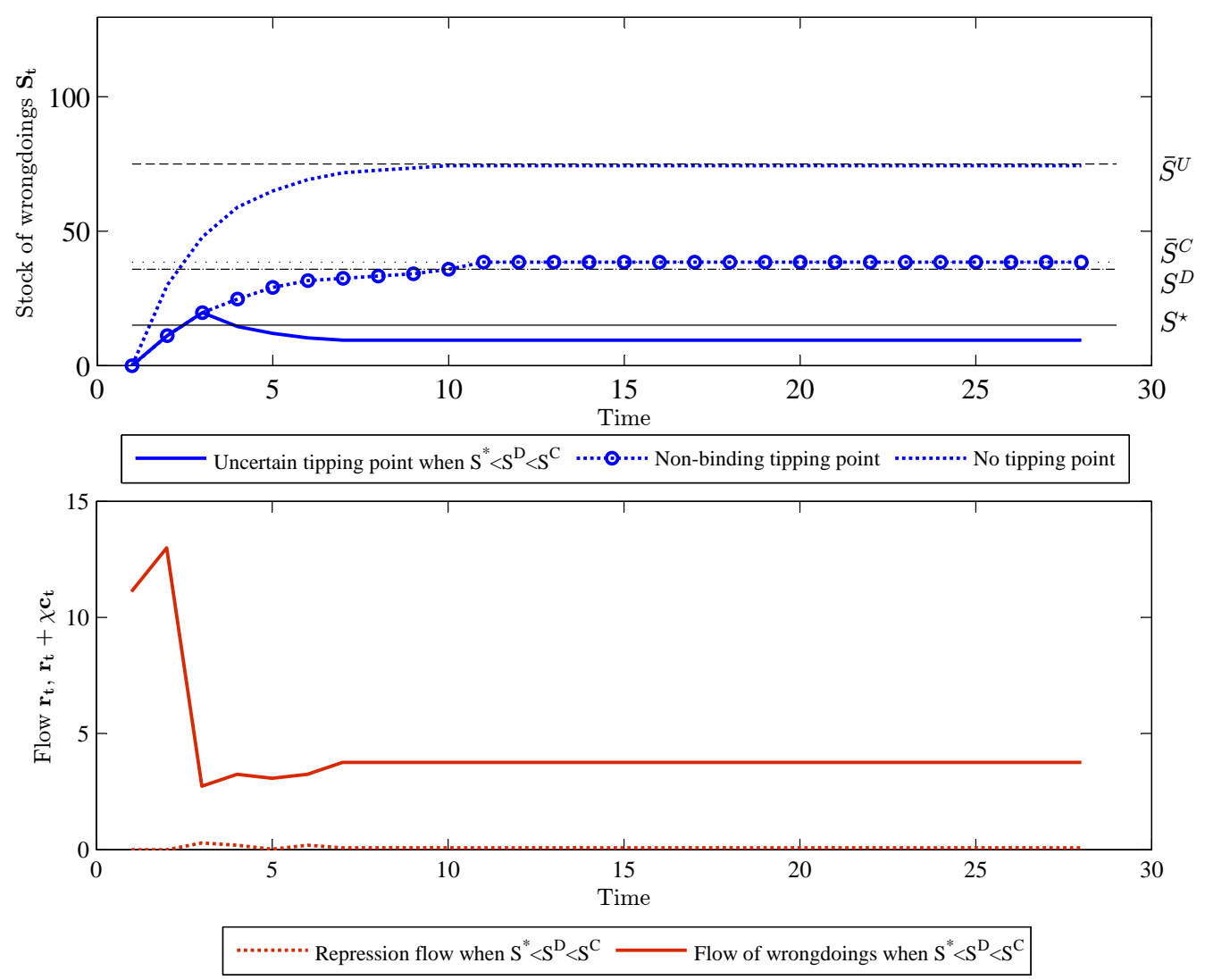

Figure 3: Evolution of key variables when $S^{D}>S^{*}$. Parameters as in Figure 1.

Note from the bottom panel of Figure 3 how in our baseline specification the dictator's wrongdoings in the pre-tipping regime only consist of rent extraction (there is no repression yet). As explained under Case I, this is due to our assumption that the dictator is non-sadistic in a sense that he does not derive any direct benefits from repressing his population. After all, the whole point of Case I was to show that even such a non-sadistic ruler can develop into a repressive tyrant.

But as some of the "bad-turned-good"-examples mentioned in the Introduction and Appendix arguably did show sadistic behavior during their early days (while Coolidge and Segal (2009) offer psychological evidence that many dictators suffer from a sadistic personality disorder), Figure 4 shows that the reverse is possible as well: even sadists can 
be turned into behaving autocrats. We model sadism by modifying the dictator's utility function to $u=\log \left(c_{t}\right)+\rho \log \left(r_{t}\right)$, with $\rho>0$. As Figure 4's bottom panel shows, such a dictator starts repressing his population as of day 1 already (very much like Jerry Rawlings), but he still ends up as a moderate leader because his unpromising start triggers opposition before his stock of wrongdoings $S$ has crossed the "point of no return", $S^{D}$.
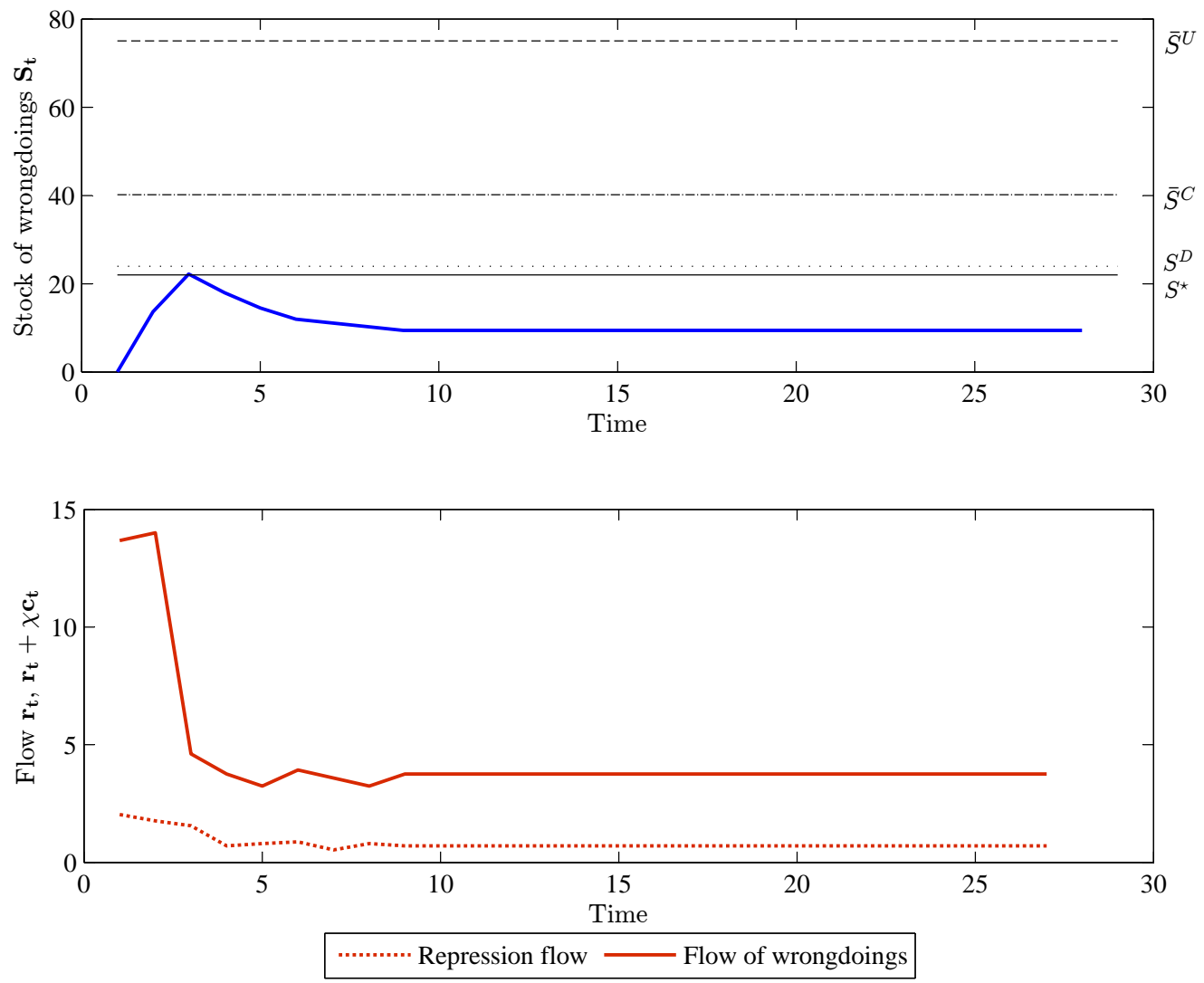

Figure 4: Evolution of key variables when $S^{D}>S^{*}$ and $\rho=0.15$. Other parameters as in Figure 1.

Along these lines one should note that our model has nothing to say about the actual democratization efforts that were undertaken in practice by Rawlings et al. (also see Section 5 on this, as this is a logical extension for future research). Our model can however explain why those regimes took the surprising step of moderating their use of political violence and repression, which is the focus of this particular paper.

Leap-frogging As Figure 5 illustrates, our model even allows for the possibility of leap-frogging. The figure simulates the behavior of two dictators, $M$ and $R$. Let's say that these two dictators are concurrently running two different countries. The difference 
however is that Dictator $R$ is intrinsically less benevolent than $M$. In particular, we assume that $R$ 's preferences are less congruent with those of his citizens than $M$ 's, while we also assume that $R$ is sadistic (while $M$ is assumed not to be). We model this by setting $R$ 's preferences equal to $u_{R}\left(c_{t}, r_{t}\right)=\alpha_{R} \log \left(c_{t}\right)+\rho_{R} \log \left(r_{t}\right)$, where $\alpha_{R}>1$ (as a result of which $R$ is more inclined to extract rents from his country than $M)$ and $\rho_{R}>0$ (this turns $R$ into a sadist, taking direct pleasure in repressing subordinates). M's utility function on the other hand continues to be given by $u_{M}\left(c_{t}, r_{t}\right)=\log \left(c_{t}\right)$.

Another important difference is that we assume that the location of the Mogadishu lines in the various countries is such that $S_{R}^{D}>S_{R}^{*}$ (as in Case II), while $S_{M}^{D}<S_{M}^{*}$ (so Dictator $M$ falls under Case I). ${ }^{23}$

As a result of $\alpha_{R}>1$ and $\rho_{R}>0$, Dictator $R$ makes a rather unpromising start repressing his population from day 1 and extracting large rents from the country. But because he comes to face significant opposition before his stock of wrongdoings has crossed $S^{D}$, he does not end up in the repressive equilibrium where a high stock $S$ has to be accompanied by heavy repression $r$, but is disciplined instead. Dictator $M$, on the other hand, walks the reverse route: he makes the better start of the two, but stoops to a heavy use of repression later on - his non-sadistic preferences notwithstanding. So despite the fact that $R$ 's preferences are "worse" than $M$ 's, and despite the fact that $R$ makes a rather unpromising start, he will still end up as the "better" autocrat. In this respect, our model supports the wider notion that external circumstances are perhaps more important in determining whether a particular individual will display "good" or "bad" behavior, than intrinsic preferences. ${ }^{24}$

Leap-frogging does not seem to be merely a theoretical curiosity: when reading newspaper accounts from the early 1980s, Jerry Rawlings is very much portrayed as the bad guy, while Robert Mugabe was simultaneously being characterized as a relatively good guy (even being considered for the Nobel Peace Prize). By the late 2000s, however, these characterizations had flipped around: most of Mugabe's international awards and honours had been revoked, while Rawlings suddenly found himself on the receiving end. Our model is able to replicate such a reversal and suggests that it may have to do with the fact

\footnotetext{
${ }^{23}$ Such a difference in the location of the $S^{*}$ 's could for example stem from a lower start-up cost for the opposition-movement in $R$ 's country, than in $M$ 's. Alternatively, it could also be driven by cultural differences (Gorodnichenko and Roland, 2014), or by a difference in the geographical structure of the two countries. As for example argued in Campante, Do, and Guimaraes (2013), successful revolutions are harder to organize in countries with isolated capital cities, as a result of which those countries will have a higher $S^{*}$ (and dictators in those countries can get away with more wrongdoings, which is in line with the empirical results reported by Campante et al.)

${ }^{24}$ In very different contexts, this idea is supported by many psychological experiments, such as the Milgram Experiment and the Stanford Prison Experiment (see Milgram (1974) and Zimbardo (2007)).
} 

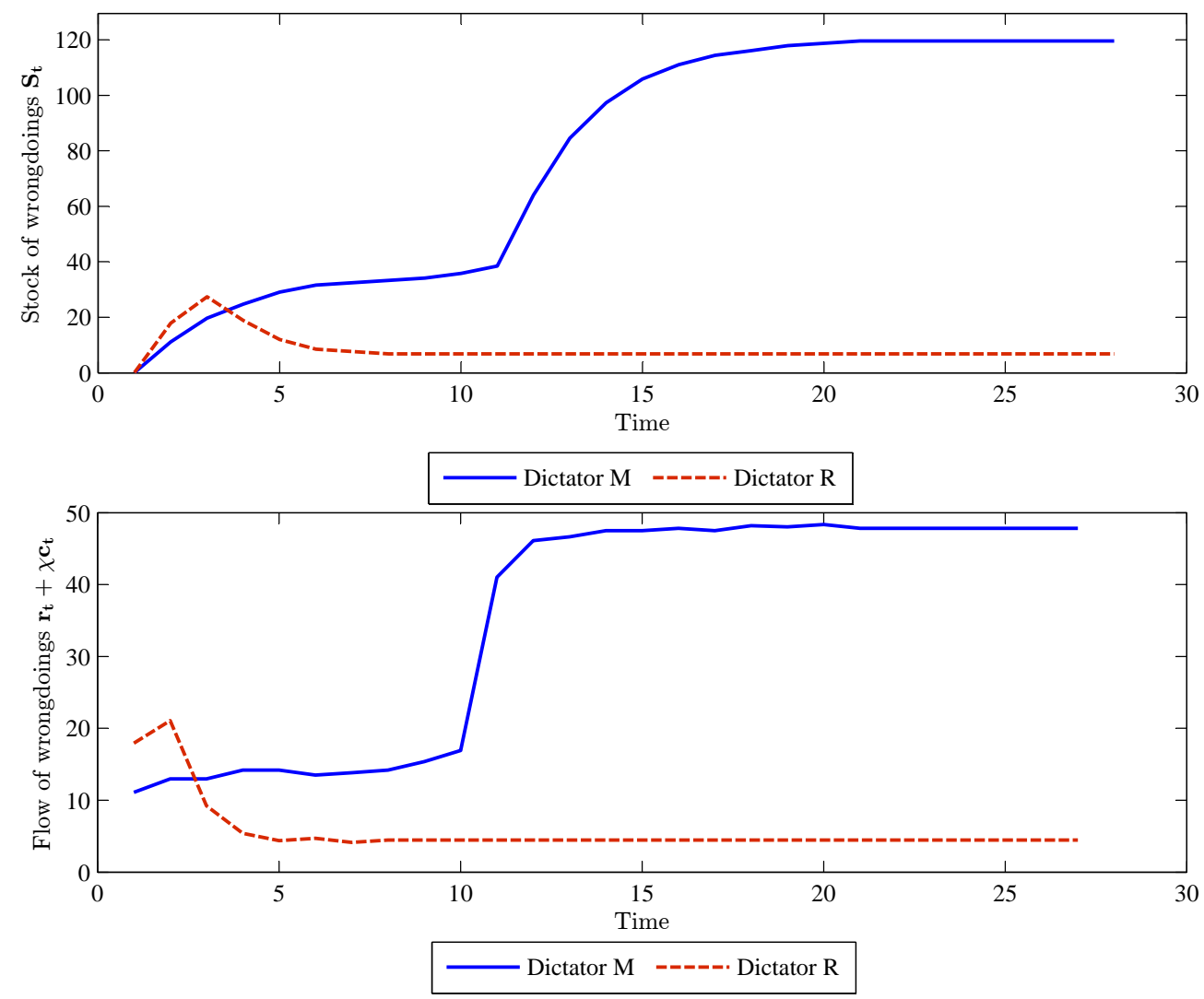

Figure 5: Evolution of key variables for Dictators $M$ and $R$ with $\alpha_{R}=1.1, \rho_{R}=0.15$, $\beta_{R}=0.99, \delta_{R}=0.35$, and $z_{R}=40$. Other parameters as in Figure 1 .

that Rawlings soon faced opposition when he started exercising repression, while Mugabe initially managed to get away with his first wrongdoings (most notably "Gukurahundi"). This, however, came back to haunt him later on.

Summarizing As this section has shown, our model implies that the mobilization of anti-government opposition has the potential to bring about a significant change to a dictator's behavior - either for the better, or for the worse. This seems to be in line with reality. Holland (2008: 87, 171) and Meredith (2009: Ch. 8) for example describe how Mugabe's regime became more repressive after he started to feel the opposition by the Zimbabwean Movement for Democratic Change. The Movement's leader at the time, Morgan Tsvangirai, seems to agree with this assessment. He has stated that "the turning point of Mugabe was when he lost an election for the first time, when he lost the support of the people, when it dawned on him the people no longer supported him. Then he 
became reactionary. He reacted to the people's will by enforcing his will on the people." 25 Similarly, the derailments of Kwame Nkrumah and Ferdinand Marcos were triggered by them having to repress anti-government protests. At the same time, dictators like Jerry Rawlings, Kenneth Kaunda, Daniel arap Moi, and Chun Doo-hwan were disciplined by the mobilization of protesters against their regimes, which is in line with our model-outcome under Case II.

This also has the provocative implication that any dictator operating in our environment has the potential to end up as either a moderate leader, or as a vicious tyrant. Interestingly, even non-sadistic individuals who have absolutely no preference for exercising repression per se can end up as repressive leaders (provided that their actions are not fully congruent with the preferences of society, which seems to be the case in reality - especially for non-accountable regimes (Maskin and Tirole, 2004)). This shines a new light upon Hannah Arendt's concept of "the banality of evil" ${ }^{26}$ Such a view is also highlighted in Orizio (2004: 4) who quotes Ian McKellen as saying that "one of the few lessons I have learned from studying people who do terrible things is that they are all too human. And that we are all too capable of doing almost anything".

Our model finally shows that something which at first sight appears to be a rather minor non-congruence in preferences between the dictator and (a subset of) the public, has the potential to escalate and lead to serious conflict. Depending on the nature of the opposition, even a difference in religion could already be enough to form the necessary friction. For example: when the Muslim Brotherhood took over power in Egypt by ousting Hosni Mubarak, his well-regarded Finance Minister Youssef Boutros Ghali was sentenced in absentia to 30 years imprisonment and an 8.6 million dollar fine for utilizing the Finance Ministry's printer for campaigning purposes, and his alleged personal use of impounded cars. His trial lasted only 6 minutes and it is believed that Boutros Ghali's Coptic-Christian background played a role in his conviction. ${ }^{27}$ These examples could make leaders who fear similar consequences more desperate in clinging on to power (even if they have delivered high-quality work, as a result of which they should have nothing to fear on objective legal grounds). When such leaders have the opportunity to do so, it may even induce them to use repression in order to avoid an unfair trial. This actually seems

\footnotetext{
${ }^{25}$ See http://www.theguardian.com/world/2014/feb/21/mugabe-celebrates-90th-birthday-zimbabweinternational-pariah.

${ }^{26}$ In her report on the trial of Adolf Eichmann, Arendt (1963) argues that ordinary people can already commit serious atrocities if ordered to do so (Mulisch (1961) developed a comparable idea in his analysis of the Eichmann-case, while Milgram's (1974) "obedience experiment" provides some scientific evidence). Our model has a similar implication, but - unlike the Arendt/Mulisch/Milgram thesis - ours does not rely upon subordinates obeying orders. Instead, our model focuses on the banality of evil at the very top.

${ }^{27}$ See http://www.newsmax.com/Newsfront/Egypt-revolution-Mubarak-Ghali/2012/02/07/id/428738.
} 
to have occurred in Bahrein, where King Hamad (who has, by most economic standards, done quite well for his country since he came to power in 1999) recently repressed protests that seemed at least partly motivated by religious differences (in Bahrein's case a Sunniruling family versus a Shia majority). ${ }^{28}$ Given that Hamad now has even more to worry about if ousted, it is likely that he is willing to use repression again in the future to avoid retribution for his past offenses.

\section{Policy implications}

Our model also carries several policy implications. First and foremost, our model points towards the importance of accountability when it comes to disciplining leaders. In environments where leaders are more accountable, $S^{*}$ will be lower such that any behavior which is non-congruent with the preferences of society is sooner met with opposition. As set out in Section 3, this decreases the risk that the leader of such a country will derail (especially recall Case II). Along these lines, our model suggests that an increase in accountability (or more generally, the development of institutions that improve information flows and allow the public to voice their dissent) can be in the interest of both society and the dictator (as it is able to prevent him from ending up at the model's bad steady state, where the dictator suffers as well).

Secondly, it is also interesting to analyze the model's comparative statics with respect to $z$, the amount of divertible funds available to a dictator for rent extraction or repression. Such income can stem from the reception of fungible development aid or from the exploitation of natural resources. As noted by Besley and Persson (2011: 1425), there is a large empirical literature documenting the impact of resource rents on repression and civil wars, but theoretical work is scarce (Aslaksen and Torvik (2006), Acemoglu, Ticchi, and Vindigni (2010), Besley and Persson (2011), Acemoglu et al. (2012), Van der Ploeg and Rohner (2012), and Van der Ploeg (2012) being some exceptions).

As shown by Figure 6, having a lower amount $z$ of fungible resources available increases the location of the critical level $S^{D}$ while simultaneously making the high-repression steady state less repressive. Eventually, when $z$ becomes low enough, this steady state even ceases to exist. In that case, there is no risk of derailment anymore and the low-repression steady state will be the unique (and stable) point of attraction. The reason for these comparative statics is that when $z$ is lower, the dictator is no longer able to finance the high amount of repression that is necessary to sustain the very high-repression steady states.

\footnotetext{
${ }^{28}$ Cf. http://www.bbc.co.uk/news/world-middle-east-14540571.
} 
The fact that the location of the critical point $S^{D}$ is decreasing in $z$ implies that dictators with access to more divertible funds, are more likely to derail and develop into repressive tyrants. It simultaneously also worsens the bad steady state (note how the latter shifts right when $z$ increases). This suggests that the availability of fungible resources without proper checks-and-balances (remember that we condition on the dictator being non-accountable) is conducive to the derailment of leaders. This can be seen as a new and complementary form of the "resource curse".

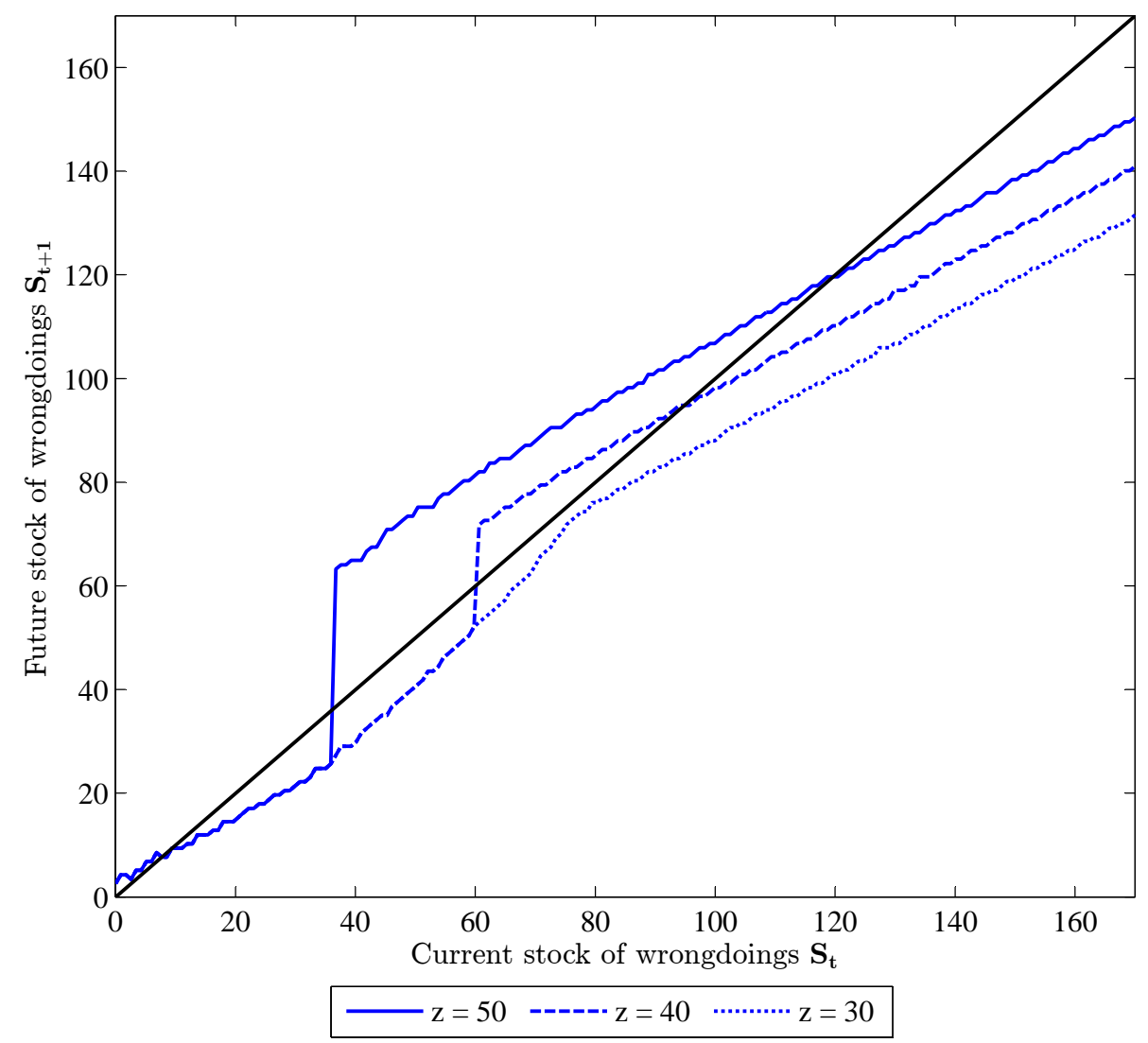

Figure 6: Impact of changes in $z$ on the post-tipping policy function. Other parameters as in Figure 1.

This prediction is consistent with some existing empirical work (even though the literature does not seem to have reached a broad consensus on this issue yet; cf. Cotet and Tsui (2013)): Besley and Persson (2011) report that exogenous aid inflows resulting from either a natural disaster or UNSC-membership during the Cold War, raise the probability of political violence. For resource income, Lei and Michaels (2014) find that oilfield discoveries increase the likelihood of armed conflict, especially for countries that have already seen such conflict in the decade before the discovery. This result could be 
due to our prediction that a dictator who has used violence in the past, is more likely to use violence again in the future to avoid retribution for his past misdeeds. Finally, Wright (2008) reports how dictators with shorter "time horizons" (for example because they face a revolutionary threat) are more likely to abuse aid income as a means to stay in power.

The idea that the availability of divertible funds contributes to the derailment of dictators, also lines up well with anecdotal evidence available for many of the aforementioned examples. As discussed in the Appendix, Kwame Nkrumah's Ghanaian government was well-funded in the mid-1950s via the revenues generated from the duties on cocoa-exports. Comparable conditions have been documented for the Philippines, Libya, and Romania. Marcos' regime in the Philippines benefitted in the early 1970s from a fourfold increase in the price of copra (the country's main export product), while Libya and Romania saw its leaders (Gaddafi and Ceausescu) derail in the 1970s, when their governments were well-endowed after having profited from increases in the oil price (with Libya being an oil producer and Romania managing to generate "hard currency" during the oil crisis by exporting refined petroleum products; cf. Roper (2000: 55)). Similarly, it has been reported that Mugabe's government uses revenues generated by the exploitation of diamond fields for repressive purposes (giving rise to so-called "blood diamonds", see Human Rights Watch (2009)).

An analogous pattern can be observed around fungible resources stemming from development aid: Alberto Fujimori's self-coup (which signaled the beginning of his repressive days) took place less than a year after Peru had received a low-interest rate IMF-loan (Hudson, 1993: 174), while Robert Mugabe's behavior first deteriorated during the 1980s - a decade in which his government was well-funded thanks to large aid inflows. ${ }^{29}$ These aid inflows were meant to reward Mugabe for his benevolent behavior. Paradoxically, our model however implies that through this reward-system, Mugabe's promising start may actually have contributed to his subsequent derailment (also see Meredith (2009: 81) who recounts how Mugabe abused aid donations for purposes of repression).

At the same time, Daniel arap Moi's rule of Kenya became less repressive after the US reduced their aid flows to Moi's regime once it had become of less strategic interest following the collapse of the USSR. ${ }^{30}$ This suggests that policies aimed at limiting the amount of fungible resources available to a non-accountable ruler can be useful. The reason is twofold: not only can they reduce the probability with which a dictator derails in the first

\footnotetext{
${ }^{29}$ From 1979 to 1984 , foreign aid to Zimbabwe increased by a factor 32 (measured in 2011 dollars, it went from 26 to 849 million dollars according to World Bank data). Over the same five year period, aid to neighboring and similarly-populated Angola only doubled (it went from 120 to 285 million dollars).

${ }^{30}$ According to World Bank data, aid to Kenya fell from 2 billion dollars in 1989 to 442 million in 1999 (all measured in 2011 dollars) - a reduction of more than 75 percent.
} 
place, but they might also be able to liberate a country from the bad, repressive steady state. Cuts in the amount of fungible development aid provided to a non-accountable regime, as well as trade-sanctions, could fulfill such a role.

\section{Discussion}

This paper constitutes a first step in providing an answer to an intriguing and important question: why have some promising, seemingly well-intentioned rulers turned into dreaded tyrants, while some ruthless dictators have made the opposite journey? Several important matters are left for future research. Most notably, our paper is very much focused at modeling the behavior of a dictator in the face of a novel complementarity (that between his stock of wrongdoings and his flow use of repression) and studying its interaction with the experimentation-process associated with the dictator's imperfect foresight. These elements have been neglected by earlier studies, but our novel focus comes at the expense of a less refined representation of the institutional environment. Our model for example abstracts from the intricate issues relating to the collective-action problems associated with opposition-mobilizations, ${ }^{31}$ while it also takes the form of government (dictatorship) as given. Consequently, it would be interesting to model the institutional framework as well and investigate under what conditions autocrats can be made willing to share power. This is the focus of Acemoglu and Robinson (1999, 2000, 2001, 2006), among others, and it could be worthwhile to combine elements of such models with those of ours.

Additionally, the model's suggestion that derailed, repressive dictators are rather unhappy and suffer from ex-post regret (recall the discussion around footnotes 21 and 22) implies that they could in principle be persuaded to step down voluntarily, since it should be possible to offer them an outside option that is better than their (poor) status quo as an unhappy dictator. History indeed suggests that this at least was the case: there are many examples of repressive autocrats who chose to step down after being offered an asylum or amnesty escape option - enabling their country to install a new leader. Some notable examples include Idi Amin, Mengistu Haile Mariam, and Ferdinand Marcos, but numerous other cases are discussed in Larcom, Sarr, and Willems (2014).

Recently, however, the international community has moved to an institutional framework (centered around the International Criminal Court, henceforth "ICC", established in 2002 and based in The Hague) in which such amnesty/asylum-abdication deals are going

\footnotetext{
${ }^{31}$ Cf. footnote 10. Also see a recent related paper by Gilli and Li (2014), which develops a further refinement by distinguishing between two groups that are able to launch a revolution: the ordinary citizenry and the "selectorate" (an elite group that holds the effective power to choose the leader).
} 
to be made less easily. The background-presence of the ICC might make it more difficult to remove repressive dictators (despite the fact that they are unhappy) as the potential prospect of having to stand trial makes them less keen to relinquish power. This allegedly prevented Mugabe from abdicating after facing electoral defeat in 2008. While Mugabe was reportedly ready to step down, his generals persuaded him otherwise as they feared an ICC-prosecution. One of Mugabe's lieutenants was quoted as saying that "[t]he Old Man is staying, because I'm not ending up in The Hague." ${ }^{32}$ What followed was an extremely violent period during which Zimbabweans had to suffer from both hyperinflation as well as a civil war accompanied by gross human rights violations.

On the positive side, the presence of the ICC holds the potential to discipline dictators and to deter them ex ante. Consequently, it is a priori not clear whether the recent move by the international community has indeed been counterproductive or not. Larcom, Sarr, and Willems (2014) analyze this issue in a simple two-period setup and it could be interesting to analyze a similar question using the framework developed in the present paper (which models the dictator's behavior in greater detail).

\section{Conclusion}

By the worst means, the worst. For mine own good, All causes shall give way. I am in blood Stepped in so far that, should I wade no more, Returning were as tedious as go o'er.

William Shakespeare, Macbeth.

In this paper, we have developed a model that can explain the observed phenomenon of dictators who, despite making a promising and seemingly well-intentioned start, end up as dreaded tyrants - and vice versa. We have shown that such mutations can result from, what at first sight appears to be, a rather minor non-congruence in preferences between the dictator and (part of) the population - for example stemming from a lack of accountability. The reason is that this initial imperfection can be greatly amplified through the complementarity in the dictator's stock of wrongdoings and his flow use of repression: when the population considers a dictator to have committed wrongs in the past, the dictator fears being overthrown as that may lead to corresponding punishment.

\footnotetext{
${ }^{32}$ See theglobeandmail.com/globe-debate/when-justice-stands-in-the-way-of-a-dictators-departure/ article623912/. Also see Godwin (2010: 122) who quotes his personal chaplain as saying in 2008 that "the Old Man is tired, he wants to go, but there are others around him who will not let him step down".
} 
Consequently, such a dictator becomes more willing to commit further wrongs (in the form of exercising repression) to reduce the probability of being ousted and punished (a channel that Shakespeare already alluded to in Macbeth, see the above epigraph). This complementarity leads to the emergence of two steady states: one where repression is low and one where repression is high. In the latter steady state the dictator actually suffers from ex-post regret, which begs the question how it is possible that he ever ended up there. This is ultimately due to the fact that our dictator has imperfect information on his ability to "get away" with non-congruent actions. As a result, he may become inclined to experiment and see how far he can push his own interests - even though this entails the risk that he may end up going too far, in which case he sees himself converging to the repressive steady state. Hereby, our model can give rise to both sudden deteriorations in behavior, as well as to sudden improvements.

In line with many of the historical accounts discussed in the Introduction, either development in our model is triggered by the mobilization of an opposition-movement against the incumbent. If this movement starts while the dictator's stock of wrongdoings is still low enough, the dictator is disciplined (as for example happened to Ghana's Jerry Rawlings). But if the dictator's stock of wrongdoings has crossed some critical level by the time the opposition mobilizes, a complete derailment of the dictator results and the model ends up in a bad steady state where repression is high (cf. the case of Robert Mugabe and Zimbabwe).

Interestingly, these results imply that anyone rising to power in our model-environment has the potential to end up as a repressive tyrant - even a non-sadistic individual who has no desire for repression per se (provided that his actions are not fully congruent with the preferences of society, which seems to be a rather mild proviso - especially for non-accountable regimes). It furthermore shows that the actions of a dictator early on in his tenure do not have to correlate very strongly with his later behavior (even if his preferences remain stable). Few people would have predicted the derailment of Robert Mugabe when he was considered for the Nobel Peace Prize in the early 1980s, and yet this is exactly what has happened.

Finally, our model implies that dictators are more likely to derail when they have more divertible funds available. This identifies a risk associated with the popular policy of rewarding well-behaving (but non-accountable) rulers with fungible aid inflows (as happened with Mugabe) and forms a new possible manifestation of the resource curse. 


\section{$7 \quad$ References}

Acemoglu, Daron, Mikhail Golosov, Aleh Tsyvinski, and Pierre Yared (2012), "A Dynamic Theory of Resource Wars", Quarterly Journal of Economics, 127 (1), pp. 283331.

Acemoglu, Daron and James A. Robinson (1999), "Democratization or Repression?", European Economic Review, 44 (4-6), pp. 683-693.

Acemoglu, Daron and James A. Robinson (2000), "Why Did the West Extend the Franchise? Democracy, Inequality, and Growth in Historical Perspective", Quarterly Journal of Economics, 115 (4), pp. 1167-1199.

Acemoglu, Daron and James A. Robinson (2001), "A Theory of Political Transitions", American Economic Review, 91 (4), pp. 938-963.

Acemoglu, Daron and James A. Robinson (2006), Economic Origins of Dictatorship and Democracy, New York: Cambridge University Press.

Acemoglu, Daron, Davide Ticchi, and Andrea Vindigni (2010), "A Theory of Military Dictatorships", American Economic Journal: Macroeconomics, 2 (1), pp. 1-42.

Adams, John (1977) [1775], Papers of John Adams, Volume 2, Cambridge: Harvard University Press.

Alesina, Alberto and Alex Cukierman (1990), "The Politics of Ambiguity", Quarterly Journal of Economics, 105 (4), pp. 829-850.

Arendt, Hannah (1963), Eichmann in Jerusalem: A Report on the Banality of Evil, New York: Viking Press.

Aslaksen, Silje and Ragnar Torvik (2006), "A Theory of Civil Conflict and Democracy in Rentier States", Scandinavian Journal of Economics, 108 (4), pp. 571-585.

Besley, Timothy (2004), "Paying Politicians: Theory and Evidence", Journal of the European Economic Association, 2 (2-3), pp. 193-215.

Besley, Timothy and Torsten Persson (2011), "The Logic of Political Violence", Quarterly Journal of Economics, 126 (3), pp. 1411-1445.

Bueno de Mesquita, Bruce and Alastair Smith (2011), The Dictator's Handbook: Why Bad Behavior Is Almost Always Good Politics, New York: PublicAffairs.

Cabrales, Antonio and Esther Hauk (2011), "The Quality of Political Institutions and the Curse of Natural Resources", Economic Journal, 121 (551), pp. 58-88.

Campante, Filipe R., Quoc-Anh Do, and Bernardo Guimaraes (2013), "Isolated Capital Cities and Misgovernance: Theory and Evidence", mimeo, Harvard Kennedy School.

Carey, Sabine C. (2006), "The Dynamic Relationship Between Protest and Repression", Political Research Quarterly, 59 (1), pp. 1-11. 
Carey, Sabine C. (2010), "The Use of Repression as a Response to Domestic Dissent", Political Studies, 58 (1), pp. 167-186.

Coolidge, Frederick L. and Daniel L. Segal (2009), "Is Kim Jong-il Like Saddam Hussein and Adolf Hitler? A Personality Disorder Evaluation", Behavioral Sciences of Terrorism and Political Aggression, 1 (3), pp. 195-202.

Cotet, Anca M. and Kevin K. Tsui (2013), "Oil and Conflict: What Does the Cross Country Evidence Really Show?", American Economic Journal: Macroeconomics, 5 (1), pp. $49-80$.

Fearon, James D. (2011), "Self-Enforcing Democracy", Quarterly Journal of Economics, 126 (4), pp. 1661-1708.

FES (2003), We Lived To Tell: The Nyayo House Story, Nairobi: FE Stiftung.

Gilli, Mario and Yuan Li (2014), "Accountability in Autocracies: The Role of Revolution Threat", Stockholm School of Economics Working Paper No. 29.

Godwin, Peter (2010), The Fear: Robert Mugabe and the Martyrdom of Zimbabwe, London: Picador.

Gorodnichenko, Yuriy and Gerard Roland (2014), "Culture, Institutions and Democratization", mimeo, UC Berkeley.

Grabsky, Phil (1997), I, Caesar: Ruling the Roman Empire, London: Butler \& Tanner.

Grossman, Herschel I. (1991), "A General Equilibrium Model of Insurrections", American Economic Review, 81 (4), pp. 912-921.

Guimaraes, Bernardo and Kevin D. Sheedy (2013), "Power Sharing, Rents, and Commitment", mimeo, LSE.

Gupta, Dipak K., Harinder Singh, and Tom Sprague (1993), "Government Coercion of Dissidents Deterrence or Provocation?", Journal of Conflict Resolution, 37 (2), pp. 301-339.

Hess, Gregory D. and Athanasios Orphanides (2001), War and Democracy", Journal of Political Economy, 109 (4), pp. 776-810.

Hudson, Rex A. (1993), Peru: A Country Study, Washington D.C.: Federal Research Division, Library of Congress.

Holland, Heidi (2008), Dinner with Mugabe: The Untold Story of a Freedom Fighter who Became a Tyrant, Harmondsworth: Penguin.

Human Rights Watch (2007), No Room to Breathe, Special Report.

Human Rights Watch (2009), Diamonds in the Rough, Special Report.

Kim, Choong Nam (2007), The Korean Presidents: Leadership for Nation Building, Norwalk: Eastbridge. 
Kuran, Timur (1989), "Sparks and Prairie Fires: A Theory of Unanticipated Revolutions", Public Choice, 61 (1), pp. 41-74.

Larcom, Shaun, Mare Sarr, and Tim Willems (2014), "What Shall We Do With the Bad Dictator?", Oxford Department of Economics Discussion Paper No. 682.

Lei, Yu-Hsiang and Guy Michaels (2014), "Do Giant Oilfield Discoveries Fuel Internal Armed Conflicts?", Journal of Development Economics, 110, pp. 139-157.

Lichbach, Mark I. (1987) "Deterrence or Escalation? The Puzzle of Aggregate Studies of Repression and Dissent", Journal of Conflict Resolution, 31(2), pp. 266-297.

Maskin, Eric and Jean Tirole (2004), "The Politician and the Judge: Accountability in Government", American Economic Review, 94 (4), pp. 1034-1054.

Meredith, Martin (2009), Mugabe: Power, Plunder and the Struggle for Zimbabwe, New York: PublicAffairs.

Mijares, Primitivo (1986), The Conjugal Dictatorship of Ferdinand and Imelda Marcos I, San Francisco: Union Square Publications.

Milgram, Stanley (1974), Obedience to Authority: An Experimental View, London: Tavistock Publications.

Moore, Will (1998), "Repression and Dissent: Substitution, Context, and Timing", American Journal of Political Science, 42 (3), pp. 851-73.

Mulisch, Harry (1961), Criminal Case 40/61, the Trial of Adolf Eichmann: An Eyewitness Account, Philadelphia: University of Pennsylvania Press.

Nordlinger, Jay (2012), Peace, They Say: A History of the Nobel Peace Prize, the Most Famous and Controversial Prize in the World, New York: Encounter Books.

Orizio, Riccardo (2004), Talk of the Devil: Encounters with Seven Dictators, London: Random House.

Orphanides, Athanasios and David Zervos (1994), "Optimal Consumption Dynamics with Non-Concave Habit-Forming Utility", Economics Letters, 44 (1-2), pp. 67-72.

Orphanides, Athanasios and David Zervos (1995), "Rational Addiction with Learning and Regret", Journal of Political Economy, 103 (4), pp. 739-758.

Regan, Patrick. M. and Errol. A. Henderson (2002), "Democracy, Threats and Political Repression in Developing Countries: Are Democracies Internally less Violent?", Third World Quarterly, 23 (1), pp. 119-136.

Rasler, Karen (1996), "Concessions, Repression, and Political Protest in the Iranian Revolution", American Sociological Review, 61(1), pp. 132-152.

Roemer, John E. (1985), "Rationalizing Revolutionary Ideology", Econometrica, 53 (1), pp. 85-108. 
Rogoff, Kenneth (1990), "Equilibrium Political Budget Cycles", American Economic Review, 80 (1), pp. 21-36.

Rogoff, Kenneth and Anne Sibert (1988), "Elections and Macroeconomic Policy Cycles", Review of Economic Studies, 55 (1), pp. 1-16.

Roper, Steven D. (2000), Romania: The Unfinished Revolution, Amsterdam: Harwood Academic Publishers.

Snyder, David (1976), "Theoretical and Methodological Problems in the Analysis of Governmental Coercion and Collective Violence", Journal of Political and Military Sociology, 4 (2), pp. 277-293.

Svolik, Milan W. (2012), The Politics of Authoritarian Rule, New York: Cambridge University Press.

Van der Ploeg, Frederick (2012), "Resource Wars and Confiscation Risk", OxCarre Research Paper 97.

Van der Ploeg, Frederick and Dominic Rohner (2012), "War and Natural Resource Exploitation", European Economic Review, 56 (8), pp. 1714-1729.

Winterling, Aloys (2011), Caligula: A Biography, Berkeley: UC Press.

Wintrobe, Ronald (1998), The Political Economy of Dictatorship, New York: Cambridge University Press.

Wright, Joseph (2008), "To Invest or Insure? How Authoritarian Time Horizons Impact Foreign Aid Effectiveness", Comparative Political Studies, 41 (7), pp. 971-1000.

Zeira, Joseph (1987), "Investment as a Process of Search", Journal of Political Economy, 95 (1), pp. 204-210.

Zeira, Joseph (1999), "Informational Overshooting, Booms, and Crashes", Journal of Monetary Economics, 43 (1), pp. 237-257.

Zimbardo, Philip (2007), The Lucifer Effect: Understanding How Good People Turn Evil, New York, NY: Random House. 


\section{Appendix}

As claimed in the Introduction, there are many more examples of promising leaders who later turned into vicious dictators. Here we describe some additional cases:

- Caligula: when he accepted the powers of Principate in $37 \mathrm{AD}$, he made a promising start by reintroducing elections for magistrates, by aiding those who lost property in fires, and by recalling Senators who were unjustly sent into exile by his predecessor Tiberius. ${ }^{33}$ But some two years into his reign, Caligula turned into one of the most vicious and oppressive dictators that the Roman Empire would ever see. ${ }^{34}$ "Let them hate me, as long as they fear me" allegedly became his motto. While some scholars hypothesize that only a mental illness can be to blame for this mutation, others disagree and believe that Caligula remained a rational and calculating individual throughout (see Winterling (2011)). In this paper, we will indeed show that it does not take a mental illness to bring about such a remarkable deterioration in behavior.

- Kwame Nkrumah: after gaining a PhD from the LSE, returning home and serving time as a political prisoner, Nkrumah was elected Prime Minister of Gold Coast (present day Ghana) in 1952. His successful policies (which included the construction of many schools and hospitals, and nearly doubling the country's literacy rate) made him very popular. However, from 1954 onwards, things started to change: when cocoa prices rose from $£ 150$ to $£ 450$ per ton, Nkrumah refused to pass any of the gain on to farmers - increasing export duties instead. This policy of rent extraction led to bloody clashes and riots, which Nkrumah answered with repression. In 1958 he passed a law that allowed imprisonment without trial, while he declared himself "President for life" in 1964. When he was overthrown in 1966, this was greeted with great enthusiasm among the Ghanaian population. Back then, The New York Times reflected on the excesses of his dictatorship and concluded that Nkrumah had at some stage crossed "a point of no return".

- Bashar al-Assad: succeeding his father as President of Syria in 2000, this Londontrained eye doctor made a promising start. He released over 600 political prisoners,

\footnotetext{
${ }^{33}$ The Roman historian Flavius Josephus wrote that Caligula "administered the Empire quite highmindedly during the first and second years of his reign. By exercising moderation he made great advances in popularity both with the Romans themselves and with their subjects" (Antiquitates Judaicae (18.256)).

${ }^{34}$ Grabsky (1997, Ch. 3) attributes a similar development to Nero (who ruled from 54 to 68 AD): while he did very well for the Roman Empire in the first five years of his reign, Nero subsequently faced violent protests - sparked by the tax increases that he implemented to finance the construction of his "Golden House". This allegedly turned him into an oppressive tyrant.
} 
closed the notorious "Mezzeh prison" (turning it into an institute for historical science), and relaxed limits to freedom of expression by tolerating critical media and permitting the use of mobile phones and internet. Consequently, many observers spoke of the "Damascus Spring" (cf. Human Rights Watch (2007, Ch. 3)). This Spring however turned out to be short-lived, as the regime had turned more repressive than ever by 2005. ${ }^{35}$ With the start of the Syrian Civil War in 2011, Assad's behavior has continued to worsen (the suspected use of chemical weapons against his own population in 2013 is only one example of this).

While the above list is far from exhaustive (similar deteriorations in behavior have been attributed to Nicolae Ceausescu of Romania, to Alberto Fujimori of Peru, to Muammar Gaddafi of Libya, and to Ferdinand Marcos of the Philippines), one can also find more examples of individuals who have followed the trajectory of Jerry Rawlings (improving behavior during the course of their tenure):

- Kenneth Kaunda: upon taking power in Zambia in 1964, Kaunda unveiled himself as a repressive autocrat. By 1972 he had transformed Zambia into a one-party state and from 1976 onwards he governed through emergency rule. During the 1980s, however, swayed by anti-government demonstrations, Kaunda became less repressive and in 1990 he even legalized opposition parties. After losing the multiparty 1991 election, Kaunda peacefully handed power to the election-winner Frederick Chiluba. Since then, Kaunda has received many awards for his contributions towards Zambian development, including numerous honorary doctorates, the second Ubuntu Award (the first recipient being Nelson Mandela), and the African President-in-Residence Fellowship at Boston University. Commenting upon that honour, The New York Times wrote on November 13, 2002 that Kaunda "would not have been eligible if the fellowship had been around thirty years ago, around the time he banned multiparty politics. Over the years, however, he became a democrat."

- Daniel arap Moi: his Presidency of Kenya can also be divided in two parts. The early period from 1978 until 1991 is typically characterized as a time of heavy corruption and repression, while the later phase from 1992 until 2002 is seen as a period during which his behavior improved: he reduced the amount of repression, restored the multiparty system, and loosened restrictions on freedom of speech. Being barred from reelection in 2002 (by his own 1992 constitutional change), Moi chose not to amend the constitution but gave his support to Uhuru Kenyatta instead. When

\footnotetext{
${ }^{35}$ See e.g. "The Enigma of Damascus" in The New York Times of July 10, 2005.
} 
the latter faced electoral defeat by Mwai Kibaki, Moi transferred power peacefully nevertheless. The improvement in Moi's behavior is attributed to a combination of both internal resistance (most notably the "Saba Saba uprising" of July 1990), as well as to reduced US support for Moi's anti-communist regime (which became of less strategic interest after the collapse of the USSR; see e.g. FES (2003)).

- Chun Doo-hwan: upon taking power in South Korea through a coup in 1979, General Chun's early days were extremely brutal. He imposed martial law, banned all political activity, and censored the media. In 1980, Chun oversaw the "Gwangju massacre", where several hundred protesters were killed by government troops. Subsequently, his behaviour improved: he lifted martial law in 1981 and wrote a new constitution limiting the President's term to 7 years. In the following year he removed a longstanding curfew, released political prisoners, and lifted the ban on political activities. These moves led to a resurrection of violent activism, but this time Chun relied upon riot police rather than the military to deal with the protesters, thereby avoiding another massacre (Kim, 2007). Adhering to his own constitution, Chun stepped down in 1988 and transferred power to the election-winner Roe Tae-woo, who became South Korea's first democratically elected President. 